\title{
The MEDITS trawl survey specifications in an ecosystem approach to fishery management
}

\author{
Maria Teresa Spedicato ${ }^{1}$, Enric Massutí ${ }^{2}$, Bastien Mérigot ${ }^{3}$, George Tserpes ${ }^{4}$, Angélique \\ Jadaud $^{5}$, Giulio Relini ${ }^{6}$ \\ ${ }^{1}$ COISPA Tecnologia \& Ricerca, via dei trulli 18, 70126 Bari, Italy. \\ (MTS) (Corresponding author) E-mail: spedicato@coispa.it. ORCID iD: https://orcid.org/0000-0001-9939-9426 \\ ${ }^{2}$ Intituto Español de Oceanografía, Centre Oceanogràfic de les Balears, Moll de Ponent s/n, 07015 Palma, Illes Baleares, \\ Spain. \\ (EM) E-mail: enric.massuti@ieo.es. ORCID iD: https://orcid.org/0000-0002-9524-5873 \\ ${ }^{3}$ MARBEC - Université de Montpellier, CNRS, Ifremer, IRD, Sète, France. \\ (BM) E-mail: bastien.merigot@umontpellier.fr. ORCID iD: https://orcid.org/0000-0001-5264-4324 \\ ${ }^{4}$ Hellenic Centre for Marine Research, Institute of Marine Biological Resources and Inland Waters, PO Box 2214, 71003 \\ Heraklion, Greece. \\ (GT) E-mail: gtserpes@ hcmr.gr. ORCID iD: https://orcid.org/0000-0001-9052-4091 \\ ${ }^{5}$ MARBEC - IFREMER, IRD, Université de Montpellier, CNRS, Avenue Jean Monnet, CS 30171, 34203 Sète Cedex, \\ France. \\ (AJ) E-mail: ajadaud@ifremer.fr. ORCID iD: https://orcid.org/0000-0001-6858-3570 \\ ${ }^{6}$ Dipartimento di Scienze della Terra, dell'Ambiente e della Vita (DISTAV), Università di Genova, Corso Europa 26, \\ 16132 Genova, Italy. \\ (GR) E-mail: biolmar@unige.it. ORCID iD: https://orcid.org/0000-0003-2502-5581
}

\begin{abstract}
Summary: The MEDITS programme started in 1994 in the Mediterranean with the cooperation among research institutes from four countries: France, Greece, Italy and Spain. Over the years, until the advent of the European framework for the collection and management of fisheries data (the Data Collection Framework, DCF), new partners from Slovenia, Croatia, Albania, Montenegro, Malta and Cyprus joined MEDITS. The FAO regional projects facilitated the cooperation with nonEuropean countries. MEDITS applies a common sampling protocol and methodology for sample collection, data storage and data quality checks (RoME routines). For many years, MEDITS represented the most important data source supporting the evaluation of demersal resources by means of population and community indicators, assessment and simulation models based on fishery-independent data. With the consolidation of the DCF, MEDITS routinely provides abundance indices of target species for tuning stock assessment models of intermediate complexity. Over the years, the survey scope has broadened from the population of demersal species to their fish community and ecosystems, and it has faced new challenges, such as the identification of essential fish habitats, providing new scientific insights linked to the Marine Strategy Framework Directive (e.g. biodiversity, trophic webs, allochthonous species and marine macro-litter evaluations) and to the ecosystem approach to fishery and marine spatial planning.
\end{abstract}

Keywords: demersal resources; trawl survey; sampling; Mediterranean.

Especificaciones de las campañas de arrastre MEDITS en un enfoque ecosistémico para la gestión pesquera

Resumen: El programa MEDITS comenzó en 1994 en el Mediterráneo, con la cooperación entre institutos de investigación de cuatro países: Francia, Grecia, Italia, España. A lo largo del tiempo, y con la puesta en marcha del programa europeo para la recopilación y gestión de datos pesqueros (Data Collection Framework, DCF), se unieron nuevos socios como Eslovenia, Croacia, Albania, Montenegro, Malta y Chipre. Los proyectos regionales de FAO han facilitado la cooperación con países no europeos. MEDITS aplica un protocolo y una metodología de muestreo comunes, que abarca desde la recolección de muestras hasta el almacenamiento de datos y los controles de calidad de los mismos (programa RoME). Durante muchos años, MEDITS ha sido la fuente de datos más importante para la evaluación de los recursos demersales, mediante indicadores de población y comunidad y modelos de evaluación y simulación, basados en datos independientes de la pesca. Con la consolidación del DCF, MEDITS proporciona rutinariamente índices de abundancia de especies objetivo, que se usan para ajustar modelos de evaluación de stocks. A lo largo del tiempo, los objetivos de las campañas se han ampliado desde las poblaciones demersales a sus comunidades y ecosistemas, afrontando nuevos desafíos, como la identificación de hábitats esenciales para los peces, y proporcionando nuevos planteamientos científicos vinculados a la Directiva Marco sobre la Estrategia Marina (p.ej. biodiversidad, redes tróficas, especies alóctonas y evaluaciones de basura marina), así como la aproximación ecosistémica a las pesquerías y la Planificación Espacial Marina.

Palabras clave: recursos demersales; campaña de arrastre; muestreo; Mediterráneo. 
Citation/Cómo citar este artículo: Spedicato M.T., Massutí E., Mérigot B., Tserpes G., Jadaud A., Relini G. 2019. The MEDITS trawl survey specifications in an ecosystem approach to fishery management. Sci. Mar. 83S1: 9-20. https://doi. org/10.3989/scimar.04915.11X

Editor: P. Abelló.

Received: February 7, 2019. Accepted: November 22, 2019. Published: December 16, 2019.

Copyright: (C) 2019 CSIC. This is an open-access article distributed under the terms of the Creative Commons Attribution 4.0 International (CC BY 4.0) License.

\section{INTRODUCTION}

The aim of scientific bottom trawl surveys is typically to collect data on the distribution of a range of fish species, estimating relative abundance and biological parameters of these species (Hilborn and Walters 1992, Gunderson 1993). The use of quantitative indices obtained is manifold. These surveys are central to the knowledge of the status of commercially important fishery stocks and to forecasting how this status evolves over time (e.g. Trenkel et al. 2007).

In data-rich situations, when both fishery-dependent and fishery-independent data are available, indices of fish population structure by age or length or indices of the whole population are used for tuning age-structured or production stock assessment models. However, for several by-catch species or for stocks that are not the main target of the commercial fisheries, fishery-dependent data are sometimes of poor quality because of incompleteness of the time series, spatial coverage or misreporting (Cotter et al. 2009a). In these data-limited situations, trawl surveys can provide valuable information in terms of quantitative abundance indices, length and/or age structure and biological parameters. Indeed, trawl surveys have gained more attention during the last decade as a primary tool for providing information that is useful per se to the assessment process (e.g. Cotter et al. 2009b).
The MEDITS trawl survey programme in the Mediterranean started in 1994 as a European Commissionfunded project in the framework of the cooperation between research institutes from four Member States of the European Union: France, Greece, Italy and Spain (Bertrand et al. 2002). During the following years, the survey was expanded to Slovenia, Croatia, Albania, Malta, Montenegro and Cyprus, finally involving 16 research institutes. Currently, the MEDITS sampling covers 543000 $\mathrm{km}^{2}$ with, on average, about 1283 sampling stations per year (Fig. 1; Table 1). Collaboration with non-European countries was facilitated by the FAO AdriaMed regional project and in 2000-2001 by the CopeMed project, for the conducting of two surveys in Morocco.

In 2002, the European countries bordering the Mediterranean made a commitment to carry out MEDITS surveys yearly according to the European Data Collection Framework (DCF). Permanent links are therefore maintained with the relevant bodies at European Union level, such as the Regional Coordination Group of the Mediterranean and Black Sea (RCG_Med\&BS) and the Scientific Technical and Economic Committee for Fisheries (STECF). Furthemore, links were also maintained with the General Fisheries Commission for the Mediterranean (GFCM), the FAO regional fisheries management organization.

The MEDITS data have been used for joint publications, which have elucidated several aspects related to

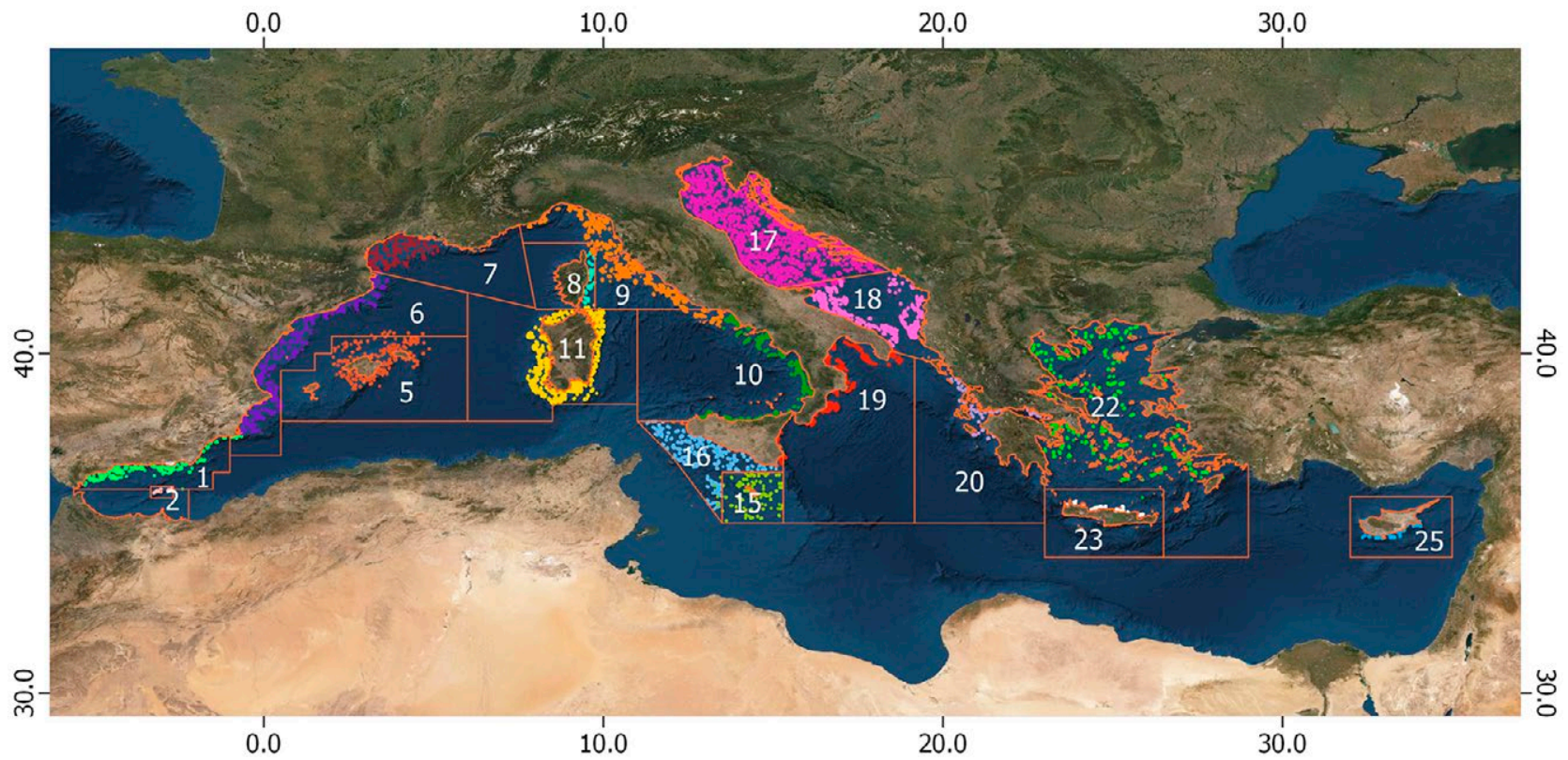

Fig. 1. - Study area of the MEDITS bottom trawl surveys, showing the hauls allocated to the geographical sub-areas established by the General Fisheries Commission for the Mediterranean. 
Table 1. - Average number of hauls carried out during the MEDITS bottom trawl surveys by each geographical sub-area (GSA) established by the General Fisheries Commission for the Mediterranean during the period 1994-2001 (before the DCF) and the period 20022017. The codes of the MEDITS macrostrata (see Fig. 3) and the relative areas in $\mathrm{km}^{2}$ are also shown.

\begin{tabular}{|c|c|c|c|c|}
\hline \multirow{2}{*}{ GSA } & \multirow{2}{*}{ Macrostrata code } & \multirow{2}{*}{ Area $\left(\mathrm{km}^{2}\right)$} & \multicolumn{2}{|c|}{ Hauls } \\
\hline & & & 1994-2001 & 2002-2017 \\
\hline 1 & $111 \mathrm{a}$ & 11920 & 34 & 44 \\
\hline 2 & $111 b$ & 833 & & 7 \\
\hline 5 & 115 & 12656 & 4 & $55^{\$ \$}$ \\
\hline 6 & $112-113$ & 32506 & 69 & 85 \\
\hline 7 & 121 & 13860 & 67 & 64 \\
\hline 8 & 131 & 4562 & 20 & 22 \\
\hline 9 & 132 & 42410 & 153 & 120 \\
\hline 10 & $134 a-134 b$ & 20255 & 85 & 70 \\
\hline 11 & 133 & 26975 & 120 & 99 \\
\hline 15 & 135 & 10580 & 7 & 45 \\
\hline 16 & $134 \mathrm{c}$ & 31386 & 56 & 120 \\
\hline $17(W)$ & $211 a-211 b$ & 60350 & 86 & 120 \\
\hline $17(\mathrm{NE})$ & 211c & 184 & $2^{\circ \circ}$ & 2 \\
\hline 17 (CE) & $211 d$ & 31727 & $48^{\circ \circ}$ & 60 \\
\hline $18(\mathrm{~W})$ & $221 \mathrm{e}-221 \mathrm{~h}$ & 15273 & 72 & 70 \\
\hline $18(\mathrm{E})$ & $221 \mathrm{j}$ & 5000 & & $5^{\$}$ \\
\hline $18(\mathrm{SE})$ & 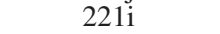 & 8735 & $40^{\circ \circ}$ & 15 \\
\hline 19 & $221 a-221 d$ & 16347 & 74 & 70 \\
\hline 20 & $222 a-222 b$ & 16823 & 31 & 36 \\
\hline 22 (Ar) & $223 a$ & 24916 & 22 & 23 \\
\hline 22 (NAe) & $224 a$ & 68157 & 65 & 65 \\
\hline $22(\mathrm{SAe})$ & $225 \mathrm{a}$ & 55258 & 38 & 40 \\
\hline 23 & $225 \mathrm{a}(06-10)$ & 7343 & 16 & 20 \\
\hline 25 & $321 \mathrm{a}$ & 11106 & & $26 * *$ \\
\hline 3 & 114 & 13841 & $55 *$ & - \\
\hline
\end{tabular}

${ }^{\circ}$ since 1996; * southern Alboran Sea; ** since 2005; \$\$ since 2007; ${ }^{\$}$ since 2008 .

abundance and biomass indices of demersal species, their length-/age-frequency distribution (by sex and maturity stages) and life history parameters, the latter especially related to total and fishing mortality. Population and community indicators and spatial occupation indices have also been estimated. All these results have provided information among the various GFCM geographical sub-areas (GSAs) of the Mediterranean for a range of target species and thematic areas. The first MEDITS monograph published in 2002 under the title "Mediterranean marine demersal resources: The MEDITS international trawl survey (1994-1999)" (Abelló et al. 2002) is the earliest good example of a joint publication at the wide geographical scale of the northern Mediterranean. Furthermore, studies have been carried out to understand the impact of fishing pressure on the abundance of populations, fish community diversity and structure, as well as to investigate the influence of environmental drivers on shaping the spatial and temporal distribution of fish populations and their communities, thus helping forecast the effects of global changes at a Mediterranean scale. Taxonomic studies, including new reports in the area and descriptions of new species, have also been carried out from samples collected during MEDITS surveys.

A list of relevant publications is provided in the Supplementary Material.

Twenty-five years after the beginning of the MEDITS trawl survey, this second monograph aims to further understanding spatial and temporal patterns of populations and fish community structures and to explore the influence of anthropogenic factors in shaping such patterns.
This paper aims to summarize and update the specifications of the MEDITS trawl survey, focusing on those most relevant to an ecosystem approach to fishery management and on data quality. The latter is pivotal for a sound evaluation of the status of demersal resources and their communities.

\section{A SUMMARY OF THE TECHNICAL SPECIFICATIONS OF THE MEDITS SURVEY}

Since the beginning of the project, the standard sampling gear has been the bottom trawl GOC 73 (Bertrand et al. 2002) designed for experimental fishing for scientific purposes in the various conditions encountered in the whole survey area. It has a vertical opening slightly larger than that of the most common professional gears used in the area. Its codend mesh size is $20 \mathrm{~mm}$ (stretched mesh) to also allow the catch of juveniles of many species for estimating recruitment indices. Specific studies have been conducted to increase knowledge on the efficiency of the gear (Fiorentini et al. 1996, Fiorentini and Dremière 1996, Dremière et al. 1999, Fiorentini et al. 1999). Both research and commercial vessels are used, depending on the GSA and country, so operational conditions in the GSAs differ.

Haul duration is 30 minutes on the continental shelf (10-200 $\mathrm{m}$ depth) and 60 minutes on the slope (201$800 \mathrm{~m}$ depth). The standard fishing speed is 3 knots on the ground, and hauls are allowed only during daytime. Haul performance and gear geometry are usually monitored using the SCANMAR system or, more recently, SIMRAD or MARPORT sensors. Data acquisition is monitored in real time using a laptop and specific software. Effective tow duration was considered as the interval from the time when the gear is stabilized on the bottom and the time when speed is reduced to recover the warp. Vertical and horizontal openings (wings) of the net working on the bottom are expected to range from 2 to $3 \mathrm{~m}$ (more commonly 2 and $2.5 \mathrm{~m}$ ) the former and from 15 to $22 \mathrm{~m}$ the latter, the higher values depending on depth. On each haul, the horizontal opening is used to standardize abundance and biomass of catches in relation to the sampled surface.

In addition, probes are used to record water temperature (formerly using Minilog and currently DST Logic CTD sensors) on the bottom during the towing. Intercalibration to exchange knowledge and fine tuning of the application of the common protocols in the field activities have been pursued since the beginning of the MEDITS survey, especially through the exchange of scientists on board the vessels. Furthermore, intercalibration studies have been performed in some GSAs to evaluate vessel effect when a change was needed. For example, this was done between the research vessels Cornide de Saavedra, used in GSAs 1 (northern Alboran), 2 (Alboran Island), 5 (Balearic Islands) and 6 (northern Spain), and Miguel Oliver, as the former had to be replaced. The intercalibration study was conducted in GSA 6 using parallel hauls and did not show significant differences.

The potential impact of different methods for estimating wing opening on the standardized abundance 


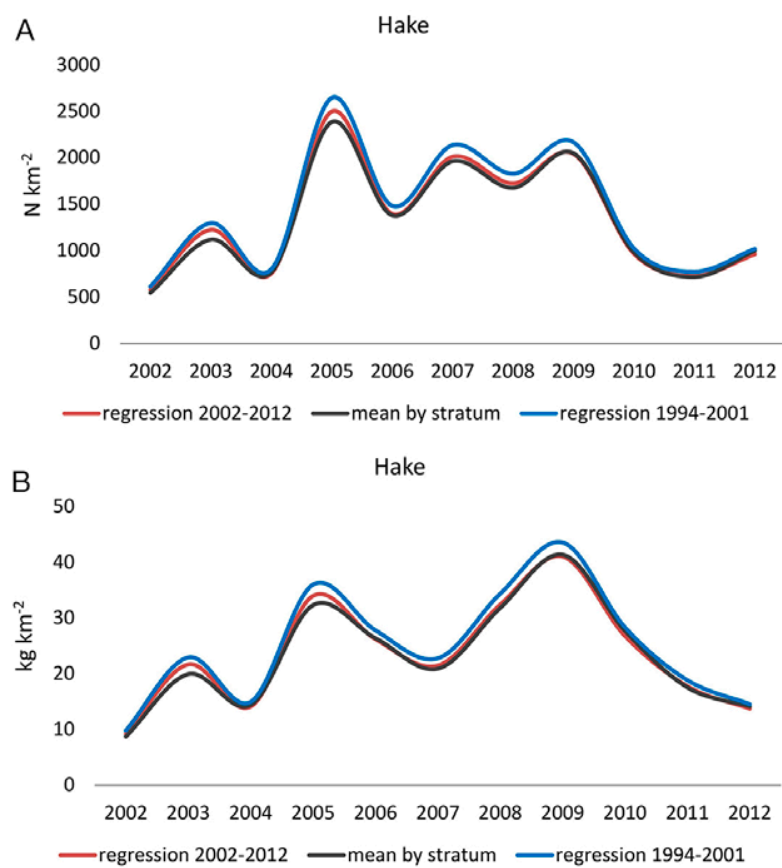

Fig. 2. - Comparison of the abundance indices (A, abundance in $\mathrm{N} \mathrm{km}{ }^{-2}$; B, biomass in $\mathrm{kg} \mathrm{km}^{-2}$ of European hake) as means by stratum, obtained with the values of wing opening per haul estimated from the SCANMAR monitoring system and as results of two logarithmic regressions respectively for the years 20022012 and for the years 1994-2001: $W O=14.54+0.651 \times \ln (x)$; $W O=6.7873 \times \ln ($ depth $)+133.94$, where $W O$ is the wing opening and $x$ is depth.

indices (number and $\mathrm{kg} \mathrm{km}^{2}$ ) have been tested on a case study in GSA 10 (central-southern Tyrrhenian Sea). Different models were applied to species with different depth distributions, such as European hake (continental shelf and slope), red mullet (continental shelf) and giant red shrimp (slope):

- the mean of the wing opening by depth stratum (median and mode were almost coincident with the mean, so only this metric was used)

- a logarithmic equation applied for the period 2002-2012:

$$
W O=14.54+0.651 \times \ln (x)
$$

- a logarithmic equation applied during the period 1994-2001 before the routine use of SCANMAR system for gear monitoring:

$$
W O=133.94+6.7873 \times \ln (x)
$$

where $W O$ is the wing opening and $x$ is depth.

The results highlighted that the impact on the estimates of abundance indices (both in number and weight) over 10 years (2002-2012) was, on average, around $2 \%$ if Equation (2) was compared with the mean (1) and around 8\% if Equation (3) was compared with the mean (1). This higher percentage was observed only for European hake (Fig. 2). Thus, it was considered acceptable to continue to use Equation (3), in continuity with the past, if a device for monitoring the trawl geometry could not be used in a certain GSA in a given year.

The time of the year in which the MEDITS survey is scheduled is late spring-summer (from May to July). The survey follows a depth-stratified random sampling scheme, with haul allocation being proportional to the surface of depth strata, whose limits are 10-50, 51-100, $101-200,201-500$ and 501-800 m. Up to 44 different geographic sectors are also included in the stratification. The sampling strata and the GFCM GSAs are reported in Figure 3.

Indices are calculated following the usual procedure of the stratified mean and variance (Souplet 1996):

$$
I=\sum_{i=1}^{N} W_{i} \bar{x}_{i}
$$

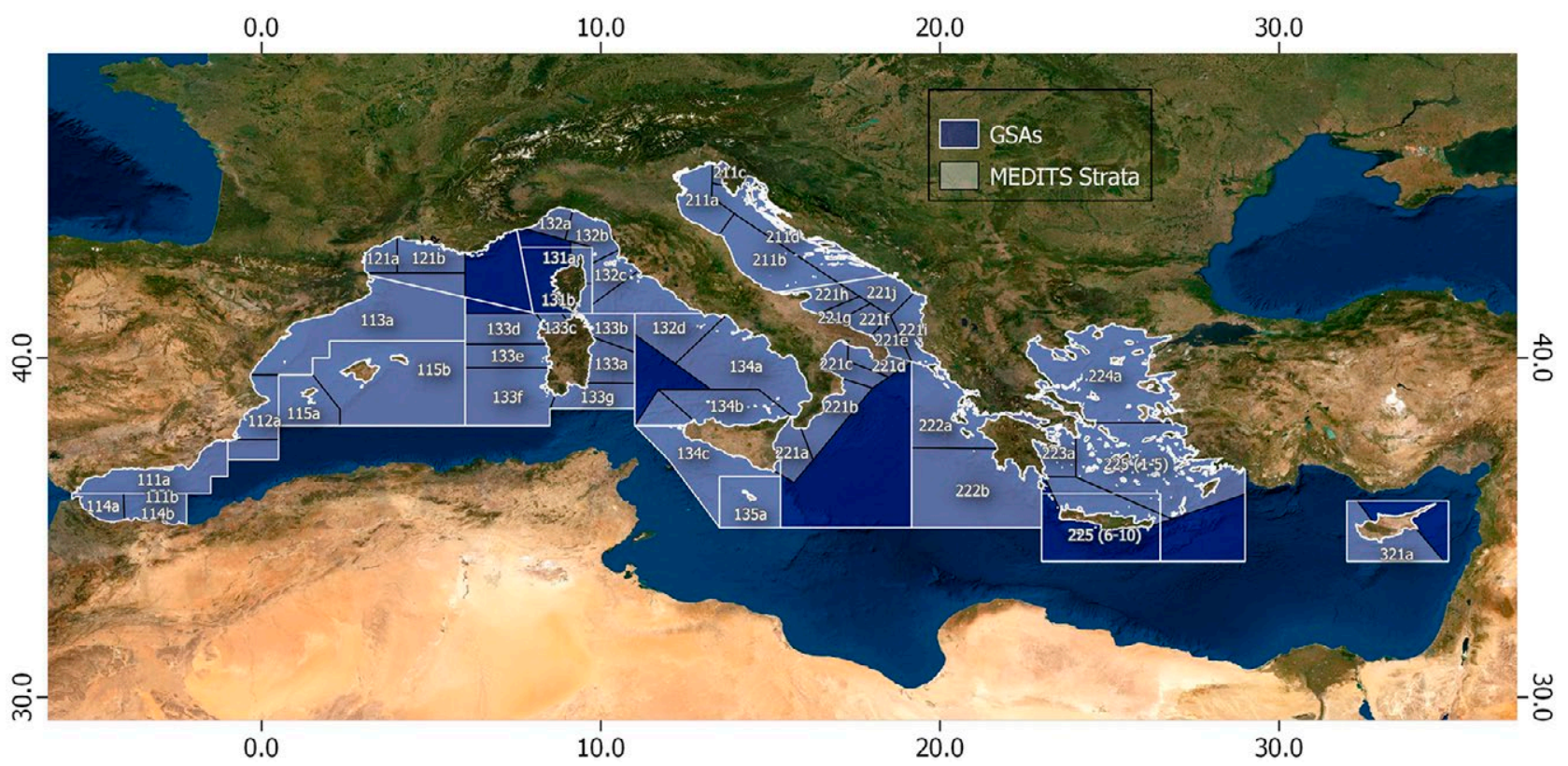

Fig. 3. - Map of the Mediterranean showing the geographic strata (black lines) considered in the MEDITS bottom trawl surveys allocated to the geographical sub-areas (GSAs; white lines) established by the General Fisheries Commission for the Mediterranean. 
Table 2. - List of the taxonomic categories used in the MEDITS bottom trawl surveys with code specification and year of introduction and use. The symbol "- " indicates that the taxonomic category is still used.

\begin{tabular}{|c|c|c|}
\hline MEDITS code & Nature & Years \\
\hline $\mathrm{A}$ & Fish & 1994-2011 \\
\hline Aa & Fish Agnatha & 2014 \\
\hline $\mathrm{Ae}$ & Fish Elasmobranchii & $2012-$ \\
\hline Ao & Fish Osteichthyes & 2012 \\
\hline $\mathrm{B}$ & Crustaceans (Decapoda) & 1994 \\
\hline Bam & Amphipoda & $2012-$ \\
\hline Bci & Cirripedia & $2012-$ \\
\hline Beu & Euphausiacea & 2012 \\
\hline $\mathrm{Bis}$ & Isopoda & 2012 \\
\hline Bst & Stomatopoda & $2012-$ \\
\hline $\mathrm{C}$ & Cephalopoda & 1994 \\
\hline $\mathrm{D}$ & Other commercial (edible) species & 1994-2011 \\
\hline Dec & Echinodermata & 2012 \\
\hline $\mathrm{Dmb}$ & Mollusca Bivalvia & 2012 \\
\hline Dmg & Mollusca Gastropoda & $2012-$ \\
\hline Dmo & Mollusca Opisthobranchia & $2012-$ \\
\hline Dtu & Tunicata (Ascidiacea) & 2012 \\
\hline $\mathrm{E}$ & Other animal species but not commercial (not edible) & 1994-2011 \\
\hline Ean & Annellida & 2014 \\
\hline Eba & Brachiopoda & $2012-$ \\
\hline Ebr & Bryozoa & 2012 \\
\hline Ech & Echiura & 2014 \\
\hline Ecn & Cnidaria & 2012 \\
\hline Ect & Ctenophora & 2012 \\
\hline Eec & Echinodermata & $2012-$ \\
\hline Ehi & Hirudinea & 2012 \\
\hline $\mathrm{Emb}$ & Mollusca Bivalvia & 2012 \\
\hline Emg & Mollusca Gastropoda & 2012 \\
\hline Emo & Mollusca Opisthobranchia & $2012-$ \\
\hline Emp & Mollusca Polyplacophora & 2014 \\
\hline Ene & Nemertea & 2014 \\
\hline Epo & Polychaeta & 2012 \\
\hline Epr & Priapulidae & 2014 \\
\hline Esi & Sipunculida & 2012 \\
\hline Esc & Scaphopoda & 2012 \\
\hline Esp & Sponges (Porifera) & 2012 \\
\hline Etu & Tunicata (Ascidiacea) & $2012-$ \\
\hline G & Portions or products of animal species (shell debris, eggs of gastropods, selachians, etc.) & 2012 \\
\hline $\mathrm{H}$ & Portions or products of vegetal species (e.g. leaves of sea grasses, of terrestrial plants, etc.) & $2012-$ \\
\hline M & Mammals & 2014 \\
\hline $\mathrm{O}$ & Birds & 2014 \\
\hline $\mathrm{R}$ & Reptilia (turtles) & 2014 \\
\hline $\mathrm{V}$ & \#Aquatic plants, macroalgae\# & 2014 \\
\hline
\end{tabular}

$$
\operatorname{var}(I)=\sum_{i=1}^{N} \frac{W_{i}^{2} S_{x_{i}}^{2}}{\sum_{j=1}^{n_{i}} A_{i, j}}\left(1-f_{i}\right)
$$

R scripts have been developed for estimating population indices. These scripts are available at https:// www.coispa.it/index.php?option=com_content\&view $=$ article\&id=34\&Itemid=119\&lang=it.

However, since the advent of the DCF, some changes have occurred: i) an increase or a decrease in the sampling intensity from the period 1994-2001 to the subsequent one; ii) a deviation of the survey season from the standard one in certain areas and years; and iii) vessel replacements without the possibility of performing field intercalibration tests. For all these reasons, modelling through GLM, GAM, Delta-GLM and Delta-GAM was suggested, both for the standardization of abundance and biomass indices and for the length-frequency distributions. R scripts have been developed for those purposes and are available at https:// www.coispa.it/index.php?option=com_content\&view $=$ article\&id=34\&Itemid=1 19\&lang=it.

\section{SUMMARY OF THE MEDITS BIOLOGICAL SPECIFICATIONS}

The focus of the collection of survey data has been on keeping consistency throughout the time, so revisions of the protocols were introduced taking care to avoid disruptions in the time series. These changes are proposed, discussed and adopted in the MEDITS coordination meetings, which are organized annually.

During the last few years more emphasis was directed towards addressing ecosystem questions, while placing the survey in the DCF. Since 2012, the taxonomic categories and lists have been expanded to take into account the needs of the Marine Strategy Framework Directive (MSFD; Directive 2008/56/EC).

All the species larger than $1 \mathrm{~cm}$ caught during the MEDITS survey are identified, then total weight and number of individuals are recorded. Alien species are also identified and noted. Currently 43 taxonomic categories are used (Table 2), linked to 1470 observed taxa (at least in one GSA). A full taxonomic list (TM list) is hence routinely updated and is currently available in the online repository (https://www.sibm.it/MEDITS\%202011/ 
Table 3. - Scientific name and code of the target species of the MEDITS bottom trawl surveys, year in which they started to be considered target and MEDITS group in which they were classified. Species belonging to the group G1, according to the MEDITS grouping of species, are in bold. * depending on the species; ** for brevity only the genus is reported (or the group of species in the case of the elasmobranchs), but the single species of the genus or of the group are considered. For further details, see Medits Handbook, Version 9 (Anonymous 2017 ).

\begin{tabular}{|c|c|c|c|}
\hline Species & Code & Year & Group \\
\hline Chelidonichthys cuculus (Linnaeus 1758) & ASPI CUC & 1998 & G2 \\
\hline Chelidonichthys lucerna (Linnaeus 1758) & TRIG LUC & 2006 & $\mathrm{G} 2$ \\
\hline Boops boops (Linnaeus, 1758) & BOOP BOO & 2006 & G2 \\
\hline Citharus linguatula (Linnaeus, 1758) & CITH MAC & 1994 & G2 \\
\hline Diplodus annularis (Linnaeus, 1758) & DIPL ANN & 2012 & G2 \\
\hline Doplodus puntazzo (Cetti, 1777) & DIPL PUN & 2012 & G2 \\
\hline Diplodus sargus (Linnaeus, 1758) & DIPL SAR & 2012 & G2 \\
\hline Diplodus vulgaris (Geoffroy Saint-Hilaire, 1817) & DIPL VUL & 2012 & G2 \\
\hline Engraulis encrasicolus (Linnaeus, 1758) & ENGR ENC & 2012 & G2 \\
\hline Epinephelus spp. ** & EPIN SPP & 2012 & G2 \\
\hline Eutrigla gurnardus (Linnaeus, 1758) & EUTR GUR & 1994 & G2 \\
\hline Helicolenus dactylopterus (Delaroche, 1809) & HELI DAC & 1994 & $\mathrm{G} 2$ \\
\hline Lepidorhombus boscii (Risso, 1810) & LEPM BOS & 1994 & G2 \\
\hline Lithognathus mormyrus (Linnaeus, 1758) & LITH MOR & 2012 & G2 \\
\hline Lophius budegassa Spinola, 1807 & LOPH BUD & 1994 & G2 \\
\hline Lophius piscatorius Linnaeus, 1758 & LOPH PIS & 1994 & G2 \\
\hline Merluccius merluccius (Linnaeus, 1758) & MERL MER & 1994 & G1 \\
\hline Micromesistius poutassou (Risso, 1826) & MICM POU & 1994 & $\mathrm{G} 2$ \\
\hline Mullus barbatus Linnaeus, 1758 & MULL BAR & 1994 & G1 \\
\hline Mullus surmuletus Linnaeus, 1758 & MULL SUR & 1994 & G1 \\
\hline Pagellus acarne (Risso, 1826) & PAGE ACA & 1994 & $\mathrm{G} 2$ \\
\hline Pagellus bogaraveo (Brünnich, 1768) & PAGE BOG & 1994 & G2 \\
\hline Pagellus erythrinus (Linnaeus, 1758) & PAGE ERY & 1994 & G2 \\
\hline Phycis blennoides (Brünnich, 1768) & PHYI BLE & 1994 & G2 \\
\hline Pagrus pagrus (Linnaeus, 1758) & SPAR PAG & 2012 & $\mathrm{G} 2$ \\
\hline Polyprion americanus (Bloch \& Schneider, 1801) & POLY AME & 2012 & G2 \\
\hline Psetta maxima (Linnaeus, 1758) & PSET MAX & 2012 & G2 \\
\hline Sardina pilchardus (Walbaum, 1792) & SARD PIL & 2012 & $\mathrm{G} 2$ \\
\hline Scomber spp. ** & SCOM SPP & 2012 & G2 \\
\hline Solea solea (Linnaeus 1758$)$ & SOLE VUL & 1994 & $\mathrm{G} 2$ \\
\hline Spicara flexuosa Rafinesque, 1810 & SPIC FLE & 1994 & G2 \\
\hline Spicara maena (Linnaeus, 1758) & SPIC MAE & 2012 & G2 \\
\hline Spicara smaris (Linnaeus, 1758) & SPIC SMA & 1998 & G2 \\
\hline Trachurus mediterraneus (Steindachner, 1863) & TRAC MED & 1994 & G2 \\
\hline Trachurus trachurus (Linnaeus, 1758) & TRAC TRA & 1994 & G2 \\
\hline Trigloporus lastoviza (Bonnaterre, 1788) & TRIP LAS & 1998 & G2 \\
\hline Trisopterus m. capelanus (Lacepède, 1800) & TRIS CAP & 1994 & G2 \\
\hline Zeus faber Linnaeus, 1758 & ZEUS FAB & 1994 & G2 \\
\hline Elasmobranchs $* *$ & & $1999-2012 *$ & G1 \\
\hline Aristeus antennatus (Risso, 1816) & ARIT ANT & 1994 & G1 \\
\hline Aristaeomorpha foliacea (Risso, 1827) & ARIS FOL & 1994 & G1 \\
\hline Nephrops norvegicus (Linnaeus, 1758) & NEPR NOR & 1994 & G1 \\
\hline Parapenaeus longirostris (Lucas, 1846) & PAPE LON & 1994 & G1 \\
\hline Palinurus elephas (Fabricius, 1787) & PALI ELE & 2012 & G2 \\
\hline Penaeus kerathurus (Forskål, 1775) & PENA KER & 2012 & $\mathrm{G} 2$ \\
\hline Squilla mantis (Linnaeus, 1758) & SQUI MAN & 2012 & G2 \\
\hline Eledone cirrhosa (Lamarck, 1798) & ELED CIR & 1994 & G2 \\
\hline Eledone moschata (Lamarck, 1799) & ELED MOS & 1997 & G2 \\
\hline Illex coindetii (Verany, 1839) & ILLE COI & 1994 & G1 \\
\hline Loligo vulgaris Lamarck, 1798 & LOLI VUL & 1994 & G1 \\
\hline Octopus vulgaris Cuvier, 1797 & OCTO VUL & 1994 & G2 \\
\hline Sepia officinalis Linnaeus, 1758 & SEPI OFF & 1994 & $\mathrm{G} 2$ \\
\hline Todarodes sagittatus (Lamarck, 1798) & TODA SAG & 2012 & G2 \\
\hline
\end{tabular}

principaledownload.htm). The procedure for including a new species in the TM list foresees that the new species's name and sheet is submitted to the person responsible for the TM list who, after checks, proposes a specific code according to the rule of the Nordic Code Centre (NCC-Stockholm).

Currently, the TM list is composed of approximately 1617 codes. Up to 2017, the identified taxa included 385 bony fish, 54 elasmobranchs, 220 crustaceans (decapods), 25 other crustaceans, 60 cephalopods, 93 echinoderms, 115 bivalve molluscs, 98 gastropod molluscs, 54 opisthobranch molluscs, 72 tunicates (mainly Ascidiacea), 28 bryozoans, 90 cnidarians, 42 polychaetes, 50 porifers, 100 aquatic plants and macroalgae and other less numerous groups. 54 taxa of bony fish and 5 elasmobranchs were recorded in all the GSAs, while for crustacean decapods 10 taxa were observed in all the GSAs (Relini 2015, Relini and Vallarino 2016, Relini and Vallarino 2017).

Among the 14 alien (non-indigenous) bony fish, 12 were recorded in GSA 25 (Relini 2015). The occurrence of 6 alien species of Crustacea decapoda was also recorded, mainly in the eastern Mediterranean (Relini and Vallarino 2016).

Since 2012, the MEDITS reference list of target species has been updated (Table 3 ) and includes 82 species, of which 32 are elasmobranchs. In addition, the list includes all species of the Epinephelus and Scomber genera, for which length measurements should be taken. 
For all these species and the two genera, total number of individuals, total weight and individual length are collected.

This list of species has been further split in two groups:

- MEDITS G1, which includes 41 species, contains 3 bony fish, 4 crustaceans, 2 cephalopods and 32 elasmobranchs. For these species total number of individuals, total weight, individual length and also biological parameters including sex, maturity, individual weight and age are collected;

- MEDITS G2, which includes 43 species for which the total number of individuals, total weight and individual length are collected.

In 2011, the MEDITS coordination meeting agreed to increase the information recorded during the MEDITS survey, including the monitoring of new biological variables such as the age of bony fish species coded G1 and the individual weight of all the species coded G1.

A length-stratified random sampling was adopted to collect these biological variables, with fixed number of individuals randomly chosen from each length class by sex to take otoliths and individual weight. For details, see the MEDITS Handbook (Anonymous 2017). These biological variables were thus added to the routinely collected information on the macroscopic maturity stage for the main taxonomic groups. All individual measures of the different species are collected following common protocols.

Maturity scales currently used for the main taxonomic groups, Osteichthyes, oviparous and viviparous Elasmobranchii, Crustacea and Cephalopoda were updated at different time steps. A first update of the maturity scales was introduced in 2007, when it was decided to better discriminate the individuals that were maturing for the first time from those that had already reproduced at least once. In addition, this update aimed to better distinguish stages in the maturation and reabsorbing processes. The final goal was to allow, as much as possible, an unbiased estimate of the size at first maturity using either the maturity ogive or mean size at maturing and mature stages. Since 2013, the maturity scale of elasmobranchs was split between oviparous and viviparous species, given the differences of these reproduction strategies.

The validation of the maturity staging has been continuously pursued over the years, with microscopic histological analysis performed by a working group on maturity staging, established in the MEDITS coordination group. At the beginning of 2013, macroscopic photos and descriptions of the full maturity scales of 68 species were collected along with photos of histological sections. This work was also enriched with observations from other seasons carried out in the DCF biological samplings and culminated in the publication of the "Atlas on the maturity stages of Mediterranean fishery resources" (Follesa and Carbonara 2019).

Also for the collection of otoliths, a dedicated working group on ageing protocols was established within the MEDITS coordination group. This work, complemented with the one carried out in the DCF biological samplings, contributed to the publication of the
"Handbook on fish age determination: a Mediterranean experience" (Carbonara and Follesa 2019).

Furthermore, these MEDITS working groups established and maintained links with the ICES Working Group BIOP (e.g. ICES 2017). This allowed a continuous update and, for example, the introduction, for the main taxonomic group, of maturity stage conversion tables between MEDITS maturity scales and other scales if differences emerged. These conversion tables allowed consistency to be maintained in the time series.

\section{ETHICAL ISSUES}

The MEDITS protocol prescribes that if a live specimen of a rare species or a species subject to conservation measures is caught, efforts should be made to obtain length, weight and sex data and return the specimen back to the sea unharmed, giving it a chance for survival. The specimens should be returned to the sea preferably within 4-5 minutes.

\section{DATA COLLECTION ON MARINE MACRO-LITTER}

In 2013, the MEDITS coordination meeting decided to introduce among the MEDITS activities the samplings of marine macro-litter, to provide data for the descriptor 10 of the MSFD. A common protocol, taking the basis from the one of Galgani et al. (1996), was hence established for the collection of these data on a voluntary basis and it was further improved in 2014 and 2015. Up to 34 different typologies have been identified in the protocol, including 9 main categories related to litter material class and 27 sub-categories related to source and main litter findings (Table 4). This table also shows a comparison with the classification adopted by the ICES International Bottom Trawl Survey (IBTS).

As a result of this activity, the MEDITS group also contributed to the actions of the United Nation Environment Programme (UNEP), the Barcelona Convention of the Mediterranean Action Plan (MAP) for implementing the Regional Plan on Marine Litter Management in the Mediterranean, and the Marine Litter Regional Cooperation Platform. This platform was established by UNEP-MAP as an open-ended group of regional and international partners participating on a voluntary basis and with mandates and activities contributing to the environmentally sound management of marine litter in the Mediterranean (available at http:// web.unep.org/unepmap/keywords/marine-litter)

\section{MEDITS DATA QUALITY}

The MEDITS protocol also establishes common formats for data storage, which include the following standard files: TA (data on the technical specifications of the hauls), TB (aggregated data on total number and weight by species), TC (aggregated data of the frequency distribution by length, sex and maturity stage by species), TE (individual data of length, weight and age by sex) and TL (data by category and subcategory of marine macro-litter). 
Table 4. - Cross-cutting table of the protocol for the collection of marine macro-litter during the MEDITS bottom trawl surveys and the ICES IBTS surveys. Main litter categories, sub-categories and respective codes are shown.

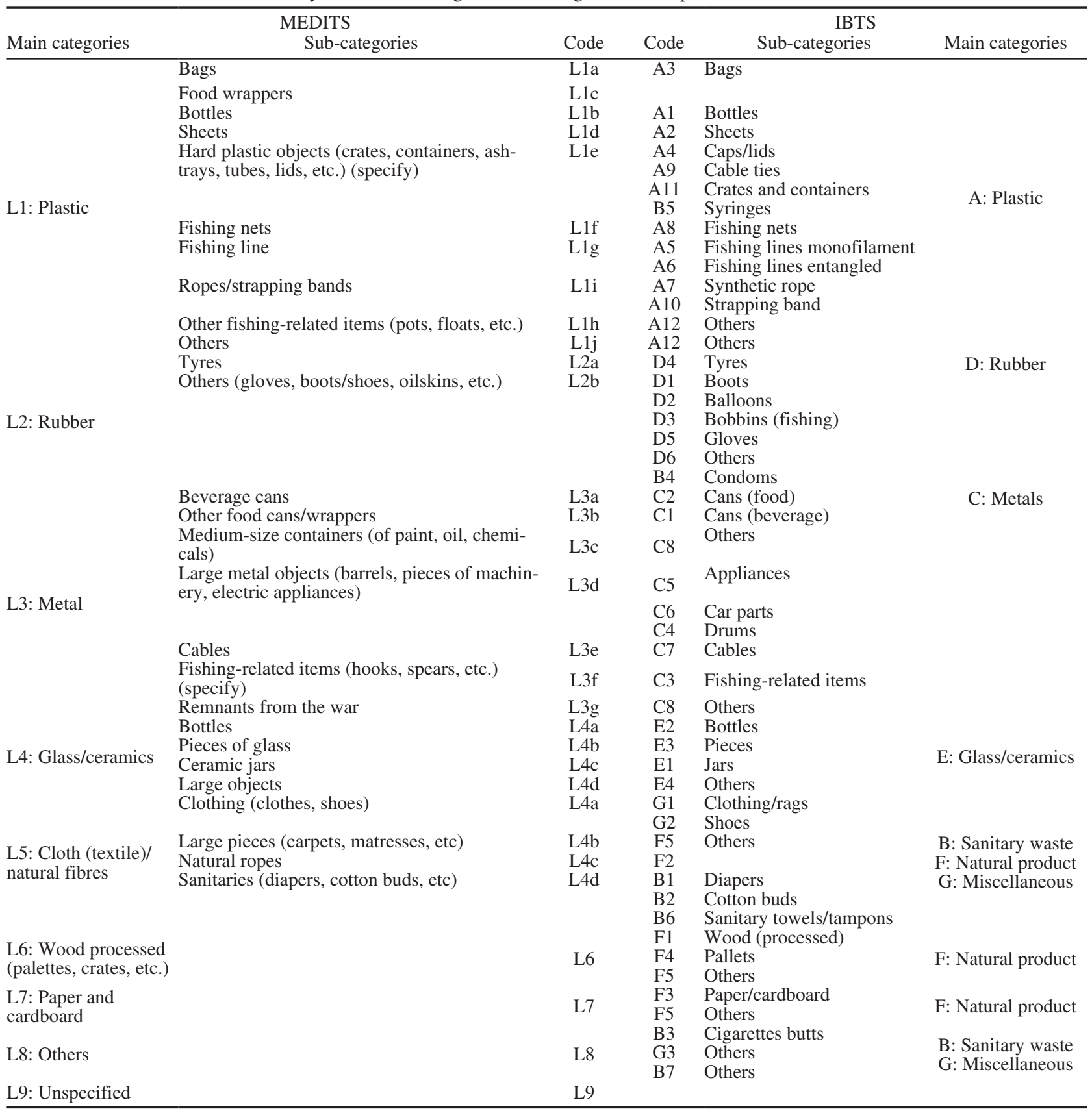

The Common Fisheries Policy sets out key principles for data quality: e.g. accuracy, reliability and timeliness, avoidance of duplication through improved coordination, safe storage in data base systems and improved availability (EC 2013). To minimize the occurrence of errors, in addition to the standardization of data collection using common protocols at the different steps of the survey implementation, common data checks on the MEDITS standard files were implemented. In 2011, the process of data quality checks was updated and standardized among the MEDITS group to unify the checks independently made by the 18 GSAs participating in the MEDITS survey.

To perform automatically the data check procedure by means of a routine enabling errors to be detected and facilitating their correction, the RoME routine, an $\mathrm{R}$ code for performing multiple and cross checks on MEDITS survey data in TA, TB, TC, TE and TL files, was developed (Bitetto et al. 2019). In version 1.3, RoME was transformed into a package structured in 55 different functions: the run is performed by means of the function $\operatorname{RoME}()$. Each function is related to a specific check and is recalled in a specific order to avoid cascade errors. This is also maintained in RoME version 1.4 .

This software does not correct the data, but it detects the errors, warning the user that there is the possibility of one or more errors, specifying the type of the error and facilitating correction of the data. The process is based on a loop of checks (errors and warnings) and 
feedbacks, so users are able to correct data but they are also advised if some deviations from the protocols occur that are not necessarily classified as errors. This also represents the basis for a data quality assurance and audit for the data to be used in the MSFD (Moriarty et al. 2019) and in the data calls of end users. The analysis carried out at EWG-STECF level evidenced that the quality of MEDITS data greatly improved when RoME was used before data upload and the Joint Research Centre checks correctly show no error patterns (STECF 2013). The data checks are performed by RoME simultaneously on the files that can also contain data of more than one year. Further specifications can be found in the RoME Manual, which can be downloaded together with the software at the following link: https://www.sibm.it/MEDITS\%202011/ principaledownload.htm.

Another point which can be a source of bias is related to the gear used during the survey, i.e. whether the technical specifications are in line with the standards adopted for the MEDITS gear. The Multidisciplinary Group on Gear Performance and Standardization of Gear Data Processing (MGGP) was established within the MEDITS coordination group. Regular checks of the MEDITS gears (trawl, rigging and doors) were introduced in 2012, and this protocol of checks was updated in 2014 and further revised in 2015 to fix some technical details. The final version is reported in the MEDITS Handbook, which also includes the work performed by this working group (MEDITS-Handbook. Version 9, Anonymous 2017).

\section{ACCESS TO MEDITS DATA}

Access to the MEDITS data is currently controlled by regulation EU 2017/1004 (recast). Data are made available for end users' needs (e.g. STECF, GFCM) through specific data calls released on an annual basis. Data can also be made available by the relevant countries for specific projects. To facilitate scientific collaborations, each year the MEDITS coordination group agrees common projects, including scientific publications based on the MEDITS data.

In addition, through contacts with the international and national coordinators, a certain number of scientists not involved in the MEDITS project can be invited to the annual MEDITS coordination meetings to present proposals for common projects and discuss the preparation of scientific papers.

\section{MEDITS DATA FOR FISHERIES ASSESSMENT}

In the Mediterranean, until the advent of the DCF, trawl survey data were considered the most important-and sometimes the only-source of reliable information for evaluating the status of stocks, fish communities and ecosystems using total mortality estimates (e.g. SAMED; Lembo 2002), assessment models based on fishery-independent data (e.g. SURBA; Needle 2003), simulation models (e.g. ALADYM; Lembo et al. 2009) and population and community indicators (Cotter et al. 2009a).
Under simple formulation and assumptions on natural mortality, MEDITS data allow estimates of total mortality to be made from the structure of the species population at sea, so that guess estimates of the exploitation rate can be obtained, an approach that is also valid in data-limited situations. The SAMED project (Lembo 2002) was a good example, outlining specific methods and approaches and providing an evaluation of several stocks in the Mediterranean (GFCM-SAC 2002). With the consolidation of the DCF, MEDITS data routinely support the stock assessment of the target species, providing relevant abundance indices for tuning the assessment models (for brevity, only the last year reports are here cited; STECF 2018a, 2018b, FAO 2018).

Furthermore, MEDITS data have been exploited in several projects to shed light on the localization of essential fish habitats, i.e. nursery and spawning grounds (e.g. Lembo 2010, Giannoulaki et al. 2013, Druon et al. 2015, Colloca et al. 2015), for fish stock identification (Fiorentino et al. 2015), to discover stability or change in biodiversity (e.g. Gaertner et al. 2010, 2013, Granger et al. 2015), to elucidate whether changes in fishing and environmental pressures are propagated bottom-up, top-down, or both (Rochet et al. 2010), to identify regional differences in changes of functional group biomass associated with regional variations of environmental factors (Brind'Amour et al. 2016), to perform a large-scale analysis of cephalopod demersal community (Keller et al. 2017), and to validate forecasts of an integrated ecosystem model at a Mediterranean-wide scale (Moullec et al. 2019).

\section{FINAL REMARKS}

The strength of the MEDITS survey so far has been the agreement among the participants to share standardized methods at a Mediterranean level using the same gear, sampling scheme and protocols for collecting, checking and analysing data. However, a shift in the survey time occurred in some situations, and the survey could be not conducted in some years because of administrative issues at national level. Implementing mitigation actions through standardization methods based on GAM modelling is possible, but this process is time-consuming and not always successful. Hence, an effort should be made to avoid disruptions in the time series of surveys as much as possible.

The experience gained in MEDITS in terms of standardization of file formats (TA, TB, TC, TE and TL) and data quality checks can be used to move forward the implementation of a common database/platform to share the effectiveness of open source visual and statistical data checks, keeping internationally available and maintained standard reference lists, sharing data for process and upon end users' requests. In fact, data accessibility and availability for scientific use is also considered a key point in the European Union (STECF 2018c). The experience gained in MEDITS in terms of data standardization and data quality checks can also be applied to recover time series of past surveys in the different countries, as was already done in the context 
Table 5. - Framework of stock categories based on available knowledge for the basis of advice in the ICES area (ICES Advice 2018; http:// www.ices.dk/community/advisory-process/Pages/default.aspx). The ICES assessment category 3 is based on scientific survey data.

\begin{tabular}{|c|c|c|c|}
\hline & & Stock categories & Advice basis \\
\hline 1 & $\begin{array}{l}\text { Stocks with quantitative } \\
\text { assessments }\end{array}$ & $\begin{array}{l}\text { Stocks with full analytical assessments and forecasts as well } \\
\text { as stocks with quantitative assessments based on production } \\
\text { models }\end{array}$ & MSY approach \\
\hline 2 & $\begin{array}{l}\text { Stocks with analytical as- } \\
\text { sessments and forecasts that } \\
\text { are only treated qualitatively }\end{array}$ & $\begin{array}{l}\text { Stocks with quantitative assessments and forecasts which for a } \\
\text { variety of reasons are considered indicative of trends in fishing } \\
\text { mortality, recruitment and biomass }\end{array}$ & MSY approach \\
\hline 3 & $\begin{array}{l}\text { Stocks for which sur- } \\
\text { vey-based assessments } \\
\text { indicate trends }\end{array}$ & $\begin{array}{l}\text { Stocks for which survey or other indices are available that pro- } \\
\text { vide reliable indications of trends in stock metrics, such as total } \\
\text { mortality, recruitment and biomass }\end{array}$ & $\begin{array}{l}\text { Precautionary approach, MSY } \\
\text { approach being developed }\end{array}$ \\
\hline 4 & $\begin{array}{l}\text { Stocks for which only reli- } \\
\text { able catch data are available }\end{array}$ & $\begin{array}{l}\text { Stocks for which a time series of catch can be used to approx- } \\
\text { imate MSY }\end{array}$ & $\begin{array}{l}\text { Precautionary approach, MSY } \\
\text { approach being developed }\end{array}$ \\
\hline 5 & Landings only stocks & Stocks for which only landings data are available & Precautionary approach \\
\hline 6 & $\begin{array}{l}\text { Negligible landings stocks } \\
\text { and stocks caught in minor } \\
\text { amounts as by-catch }\end{array}$ & $\begin{array}{l}\text { Stocks for which landings are negligible in comparison with } \\
\text { discards and stocks that are primarily caught as by-catch spe- } \\
\text { cies in other targeted fisheries }\end{array}$ & Precautionary approach \\
\hline
\end{tabular}

of the RECFISH project (Ligas 2019) for the GRUND surveys (Relini 2000).

During the last few years, a liaison with the ICES Workshop on Technical Development to Support Fisheries Data Collection (WKSEATEC) and IBTS took place. While progress in the Mediterranean has centred on implementation of standardized data checking routines across surveys, in the Atlantic and Baltic areas efforts converged towards progress in electronic data capture. Moving towards a wider implementation of paperless sampling during the measuring process using either purchased or developed in-house technology is a point to be further developed for the future in all the Mediterranean GSAs involved in the MEDITS project.

A question also rises on the use of data from scientific surveys such as MEDITS. Is the potential of this kind of information fully exploited? The usefulness of the MEDITS trawl survey time series also relies on the possibility of using these data in an assessment framework that allows them to be exploited to produce advice, even in situations in which fishery-dependent data are not available, as is being done in the ICES advice framework (Table 5).

Trawl surveys are also an accurate source of information for understanding the influence of climate change on fish populations, their communities and ecosystems. Many papers so far have tried to disentangle the effects of the anthropogenic pressure caused by fishing from the ones mainly driven by environmental variables linked to climate change, such as sea surface and bottom temperatures, using GAM modelling for example. This is a focus topic in this special issue, to better understand the underlying processes of tropicalization and its potential effect on demersal resources. Thus, it is becoming increasingly important to integrate existing knowledge on environmental drivers, fishing pressure and species interaction in the assessments of ecosystems and fisheries, in line with the ecosystem approach to fisheries management. Many papers in this special issue investigate these relationships.

Unlike in other European seas, where several trawl surveys have been historically conducted, in the Mediterranean MEDITS is the only scientific survey carried out for monitoring stocks of demersal species inde- pendently of fisheries biological sampling (EC 2016). A second scientific trawl survey, placed in a different time quarter different from the current MEDITS survey could provide useful information to improve and expand the current assessment process and the present understanding of biological processes and dynamics. It can also further assist the implementation of an ecosystem approach to fishery management. Accurate information on cartilaginous fish populations, for example, is difficult to obtain from the commercial fishery, and a single survey cannot be sufficient. This proposal has been put to the STECF (2019). The following aspects could be further improved with the availability of data from a second survey: i) capturing the most relevant biological events for a wide spectrum of stocks (e.g. different spawning seasons), including vulnerable species such as cartilaginous fish; ii) obtaining more accurate estimates of life history parameters (e.g. mortality and growth), in particular of vulnerable species; iii) improving estimates of recruitment indices; iv) obtaining more valuable records for estimating the stock-recruitment relationships; v) improving estimates of seasonal spatial occupation of the different components of the stocks, thus providing key information for a space/ season fishery management (e.g. Spedicato 2015); and vi) allowing a more robust evaluation of changes in the population and community indicators.

\section{ACKNOWLEDGEMENTS}

The MEDITS surveys are carried out within the Data Collection Framework. The European Commission and Member States of the Mediterranean countries are thankfully acknowledged.

We are grateful to all the colleagues who contribute to the activities of the MEDITS trawl surveys and to the ones who initially paved the way for the progress of MEDITS in the Mediterranean.

\section{REFERENCES}

Abelló P., Bertrand J.A., De Sola L.G., et al. (eds). 2002. Mediterranean marine demersal resources: the MEDITS international trawl survey (1994-1999). Sci. Mar. 66(Suppl. 2): 1-280. https://doi.org/10.3989/scimar.2002.66s2 
Anonymous. 2017. MEDITS Handbook, Version n. 9. MEDITS Working Group, 106 pp. http://www.sibm.it/MEDITS\%202011/principaledownload.htm

Bertrand J.A., De Sola L.G., Papaconstantinou C., et al. 2002. The general specifications of the MEDITS surveys. Sci. Mar. 66(Suppl. 2): 9-17. https://doi.org/10.3989/scimar.2002.66s2

Bitetto I., Facchini M.T., Spedicato M.T. 2019. RoME (version 1.4): R code to perform multiple checks on MEDITS Survey data (TA, TB, TC, TD, TT and TE files). https://www.sibm.it/MEDITS\%202011/RoME.htm

Brind'Amour A., Rochet M.J., Ordines F., et al. 2016. Environmental drivers explain regional variation of changes in fish and invertebrate functional groups across the Mediterranean Sea from 1994 to 2012. Mar. Ecol. Prog. Ser. 562: 19-35. https://doi.org/10.3354/meps11912

Carbonara P., Follesa M.C. (eds). 2019. Handbook on fish age determination: a Mediterranean experience. Studies and Reviews. No. 98. Rome, FAO 180 pp.

Colloca F., Garofalo G., Bitetto I., et al. 2015. The seascape of demersal fish nursery areas in the North Mediterranean Sea, a first step towards the implementation of spatial planning for trawl fisheries. PLoS ONE 10: e0119590. https://doi.org/10.1371/journal.pone.0119590

Cotter J., Petitgas P., Abella A., et al. 2009a. Towards an ecosystem approach to fisheries management (EAFM) when trawl surveys provide the main source of information. Aquat. Living Resour. 22: 243-254. https://doi.org/10.1051/alr/2009025

Cotter J., Mesnil B., Witthames P., et al. 2009b. Notes on nine biological indicators estimable from trawl surveys with an illustrative assessment for North Sea cod. Aquat. Living Resour. 22: 135-153. https://doi.org/10.1051/alr/2009016

Dremière P.-Y., Fiorentini L., Cosimi G., et al. 1999. Escapement from the main body of the bottom trawl used for the Mediterranean international trawl survey (MEDITS). Aquat. Living Resour. 12: 207-217. https://doi.org/10.1016/S0990-7440(00)88471-5

Druon J.N., Fiorentino F., Murenu M., et al. 2015. Modelling of European hake nurseries in the Mediterranean Sea: an ecological niche approach. Prog. Oceanogr. 130: 188-204 https://doi.org/10.1016/j.pocean.2014.11.005

European Commission (EC). 2013. Regulation (EU) No 1380/2013 of the European Parliament and of the Council of 11 December 2013 on the Common Fisheries Policy, Amending Council Regulations (EC) No 1954/2003 and (EC) No 1224/2009 and Repealing Council Regulations (EC) No 2371/2002 and (EC) No 639/2004 and Council Decision 2004/585/EC. European Commission, Brussels. 40 pp.

European Commission (EC). 2016. EU Commission Implementing Decision 2016. 2016/1251 of 12 July 2016 adopting a multiannual Union programme for the collection, management and use of data in the fisheries and aquaculture sectors for the period 2017-2019. $65 \mathrm{pp}$.

European Union (EU). 2008. Directive 2008/56/EC of the European Parliament and of the Council of 17 June 2008 establishing a framework for community action in the field of marine environmental policy (Marine Strategy Framework Directive) http://data.europa.eu/eli/dir/2008/56/oj

European Union (EU). 2017. EU Regulation 2017/1004 of the European Parliament and of the Council of 17 May 2017 on the establishment of a Union framework for the collection, management and use of data in the fisheries sector and support for scientific advice regarding the common fisheries policy and repealing Council Regulation (EC) No 199/2008 (recast)

FAO. 2018. Report of the twentieth session of the Scientific Advisory Committee on Fisheries. General Fisheries Commission for the Mediterranean. Tangiers, Morocco, 26-29 June 2018. FAO Fisheries and Aquaculture Report R1245, Rome, Italy. 225 pp.

Fiorentini L., Dremière P.Y. 1996. Efficacy and selectivity of the trawl used for the MEDITS project. IRPEM: $17 \mathrm{pp}$.

Fiorentini L., Cosimi G., Sala A., et al. 1996. Intercalibration des campagnes internationales de chalutage démersal en Méditerranée centrale. IRPEM. CE Med/93/015: $59 \mathrm{pp}$.

Fiorentini L., Dremière P.-Y., Leonori I., et al. 1999. Efficiency of the bottom trawl used for the Mediterranean international trawl survey (MEDITS). Aquat. Living Resour. 12: 187-205. https://doi.org/10.1016/S0990-7440(00)88470-3

Fiorentino F., Massutí E., Tinti F., et al. 2015. Stock units: Identifica- tion of distinct biological units (stock units) for different fish and shellfish species and among different GFCM-GSA. STOCKMED Deliverable 03: Final Report. January 2015, 310 pp.

https://ec.europa.eu/fisheries/documentation/studies/ stockmed en

Follesa M.C., Carbonara P. (eds). 2019. Atlas of the maturity stages of Mediterranean fishery resources. Studies and Reviews, n. 99. Rome, FAO. 268 pp.

GFCM-SAC. 2002. Report of the fourth stock assessment SubCommittee meeting (SCSA) Barcelona, Spain, 6-9 May. 118 pp.

Gaertner J.C., Mérigot B., Relini G., et al. 2010. Reproducibility of the multi-component aspect of species diversity through different areas and scales: towards the constitution of a shortlist of complementary indices for monitoring fish diversity? Ecography 33: 1123-1135. https://doi.org/10.1111/j.1600-0587.2009.06259.x

Gaertner J.C, Maiorano P., Mérigot B., et al. 2013. Large-scale diversity of slope fishes: patterns inconsistency between multiple diversity indices. PLoS ONE 8: e66753. https://doi.org/10.1371/journal.pone.0066753

Galgani F., Souplet A., Cadiou Y. 1996. Accumulation of debris on the deep sea floor off the French Mediterranean coast. Mar. Ecol. Prog. Ser. 142: 225-234. https://doi.org/10.3354/meps142225

Giannoulaki M., Belluscio A., Colloca F., et al. (eds). 2013. Mediterranean Sensitive Habitats. DG MARE Specific Contract SI2.600741, Final Report. 557 pp.

Granger V., Fromentin J.M., Bez N., et al. 2015. Large spatio-temporal monitoring highlights shift in Mediterranean fish diversity hotspots. Prog. Oceanogr. 130: 65-74. https://doi.org/10.1016/j.pocean.2014.10.002

Gunderson D.R. 1993. Surveys of fisheries resources. Wiley. New York. 248 pp.

Hilborn R., Walters C.J. 1992. Quantitative fisheries stock assessment: Choice, dynamics and uncertainty. Chapman and Hall, New York. 570 pp. https://doi.org/10.1007/978-1-4615-3598-0

Keller S., Hidalgo M., Álvarez-Berastegui D., et al. 2017. Demersal cephalopod communities in the Mediterranean: a large-scale analysis. Mar. Ecol. Prog. Ser. 584: 105-118. https://doi.org/10.3354/meps12342

ICES. 2017. Report of the Working Group on Biological Parameters (WGBIOP), 2-6 October 2017, Sardinia, Italy. ICES CM 2017/ SSGIEOM:08. $129 \mathrm{pp}$.

Lembo G. (coord.). 2002. Stock Assessment in the Mediterranean. Final Report EU Project nº 99/047.

Lembo G. (coord.). 2010. Identification and localization of main nursery areas of demersal species in the Italian sea. NURSERY. Final report (VI Plan MIPAAF), Italian Biology AssociationS.I.B.M., Genova. 119 pp.

Lembo G., Abella A., Fiorentino F., et al. 2009. ALADYM: an age and length-based single species simulator for exploring alternative management strategies. Aquat. Living Resour. 22: 233-241. https://doi.org/10.1051/alr/2009024

Ligas A. (coord.). 2019. Recovery of fisheries historical time series for Mediterranean and Black Sea stock assessment RECFISH. SC 01 Final Report (Deliverable D0.4). Framework contract for the provision of scientific advice for the Mediterranean and the Black Seas. EASME/EMFF/2016/032. $95 \mathrm{pp}$.

Moriarty M., Greenstreet S.P.R., Rasmussen J., et al. 2019. Assessing the state of demersal fish to address formal ecosystem based management needs: making fisheries independent trawl survey data 'fit for purpose'. Front. Mar. Sci. 6: 162. https://doi.org/10.3389/fmars.2019.00162

Moullec F., Velez L., Verley P., et al. 2019. Capturing the big picture of Mediterranean marine biodiversity with an end-to-end model of climate and fishing impacts. Prog. Oceanogr. 178: 102179 . https://doi.org/10.1016/j.pocean.2019.102179

Needle C.L. 2003. Survey-based assessments with SURBA. Working Document to the ICES Working Group on Methods of Fish Stock Assessment, Copenhagen, 29 January - 5 February 2003.

Relini G. 2000. Demersal trawl surveys in the Italian seas: a short review. In: Bertrand J.A., Relini G. (eds), Demersal resources in the Mediterranean. Actes de Colloques, 26. IFREMER, Plouzane: pp. 46-75.

Relini G. 2015. Fish biodiversity in MEDITS surveys. Biol. Mar. Mediterr. 22: 176-177.

Relini G., Vallarino G. 2016. Species richness of Crustacea Decapoda in MEDITS surveys. Biol. Mar. Mediterr. 23: 277-278. 
Relini G., Vallarino G. 2017. Cephalopods recorded during MEDITS surveys. Biol. Mar. Mediterr. 24: 216-217.

Rochet M.J., Trenkel V.M., Carpentier A., et al. 2010. Do changes in environmental and fishing pressures impact marine communities? An empirical assessment. J. Appl. Ecol. 47: 741-750. https://doi.org/10.1111/j.1365-2664.2010.01841.x

Souplet A. 1996. Calculation of abundance indices and length frequencies in the MEDITS survey. In: Bertrand J. (ed), Campagne internationale de chalutage démersal en Méditerranée (MEDITS). Campagne 1995 Vol. III. Rapport final de contrat CEEIFREMER-IEO-SIBM-NCMR (MED/93/020,018,006,004).

Spedicato M.T. 2015. Critical and protected habitats of the Mediterranean Sea: knowledge from the MAREA project and insights for the Maritime Spatial Planning. Biol. Mar. Medit. 22: 29-33.

Scientific, Technical and Economic Committee for Fisheries (STECF). 2013. Assessment of Mediterranean Sea stocks part I (STECF 13-22). Publications Office of the European Union, Luxembourg, EUR 26329 EN, JRC 86087. 400 pp.

Scientific, Technical and Economic Committee for Fisheries (STECF). 2018a. Mediterranean Stock Assessments - Part 1 (STECF-18-12). Publications Office of the European Union, Luxembourg. https://doi.org/10.2760/838965

Scientific, Technical and Economic Committee for Fisheries (STECF). 2018b. Mediterranean Stock Assessments - Part 2 (STECF-18-16). Publications Office of the European Union,
Luxembourg. https://doi.org/10.2760/598716

Scientific, Technical and Economic Committee for Fisheries (STECF). 2018c. Preparation for the evaluation of the list of mandatory research surveys at sea (STECF-18-04). Publications Office of the European Union, Luxembourg. https://doi.org/10.2760/956174

Scientific, Technical and Economic Committee for Fisheries (STECF). 2019. Preparation for the evaluation of the list of mandatory research surveys at sea (STECF-19-05). Publications Office of the European Union, Luxembourg.

Trenkel V.M., Rochet M.J., Mesnil B. 2007. From model-based prescriptive advice to indicator-based interactive advice. ICES J. Mar. Sci. 64: 768-774.

https://doi.org/10.1093/icesjms/fsm006

\section{SUPPLEMENTARY MATERIAL}

The following supplementary material is available through the online version of this article and at the following link:

http://scimar.icm.csic.es/scimar/supplm/sm04915esm.pdf

List of the papers peer reviewed (with or without impact factor) published between 2002 and 2017 and based on MEDITS data. 
Scientia Marina 83S1

December 2019, S1-S13, Barcelona (Spain) ISSN-L: 0214-8358

\section{The MEDITS trawl survey specifications in an ecosystem approach to fishery management}

Maria Teresa Spedicato, Enric Massutí, Bastien Mérigot, George Tserpes, Angélique Jadaud, Giulio Relini

Supplementary material

Updated on July 7, 2020 


\section{List of the papers peer reviewed (with or without impact factor) published between 2002 and 2017 and based on MEDITS data.}

Abella A., Fiorentino F., Mannini A., et al. 2008. Exploring relationships between recruitment of European hake (Merluccius merluccius L. 1758) and environmental factors in the Ligurian Sea and the Strait of Sicily (Central Mediterranean). J. Mar. Syst. 71: 279-293.

https://doi.org/10.1016/j.jmarsys.2007.05.010

Abelló P., Abella A., Adamidou A., et al. 2002. Geographical patterns in abundance and population structure of Nephrops nor vegicus and Parapenaeus longirostris (Crustacea: Decapoda) along the European Mediterranean coasts. Sci. Mar. 66 (Suppl. 2): $125-141$

https://doi.org/10.3989/scimar.2002.66s2125

Abelló P., Carbonell A., Torres P. 2002. Biogeography of epibenthic crustaceans on the shelf and upper slope off the Iberian Peninsula Mediterranean coasts: implications for the establishment of natural management areas. Sci. Mar. 66S2: 183-198. https://doi.org/10.3989/scimar.2002.66s2183

Abelló P., Arcos J.M., Gil de Sola L. 2003. Geographical patterns of seabird attendance to a research trawler along the Iberian Mediterranean coast. Sci. Mar. 67 (Suppl. 2): 69-75. https://doi.org/10.3989/scimar.2003.67s269

Abelló P., Guerao G., Salmerón F., García Raso J.E. 2014. Maja brachydactyla (Brachyura, Majidae) in the western Mediterranean. Mar. Biodivers. Rec. 7 (e77): 1-5 https://doi.org/10.1017/s1755267214000827

Arcuti S., Calculli C., Pollice A., et al. 2013. Spatio-temporal modelling of zero-inflated deep-sea shrimp data by tweedie generalized additive models. Statistica LXXIII: 87-101. https://doi.org/10.6092/issn.1973-2201/3987

Arcuti S., Pollice A., Ribecco N., et al. 2016. Bayesian spatiotemporal analysis of zero-inflated biological population density data by a delta-normal spatio-temporal additive model. Biometrical Journal 58: 372-386. https://doi.org/10.1002/bimj.201400123

Aguzzi J., Bahamon N. 2009. Modeled day-night biases in decapod assessment by bottom trawling survey Fish. Res. 100: 274-280. https://doi.org/10.1016/j.fishres.2009.08.010

Baino R., Ligas A., Mancusi C., et al. 2007. Analisi delle catture di pesci cartilaginei di acque profonde ottenute nei trawl survey dell'area toscana. Biol. Mar. Mediterr. 14: 246-247.

Banaru D., Mellon C., Roos D., et al. 2013. Trophic structure in the Gulf of Lions marine ecosystem (North-Western Mediterranean Sea) and fishing impacts. J. Mar. Syst. 111: 45-68. https://doi.org/10.1016/j.jmarsys.2012.09.010

Barnes D., Galgani F., Thomson R., et al. 2009. Accumulation and fragmentation of plastic debris in global environments. Phil. Trans. R. Soc. B. 64: 1985-1998. https://doi.org/10.1098/rstb.2008.0205

Bartolino V., Colloca F., Sartor P., et al. 2008. Modelling recruitment dynamics of hake, Merluccius merluccius, in the central Mediterranean in relation to key environmental variables Fisheries Research Fish. Res. 92: 277-288. https://doi.org/10.1016/j.fishres.2008.01.007

Battista D., Capezzuto F., Indennidate A., et al. 2011. Variazioni temporali nelle abbondanze della teutofauna del mar ionio nordoccidentale. Biol. Mar. Mediterr. 18: 330-331.

Belcari P., Cuccu D., González M., et al. 2002. Distribution and abundance of Octopus vulgaris Cuvier, 1797 (Cephalopoda: Octopoda) in the Mediterranean Sea. Sci. Mar. 66S2: 157-166. https://doi.org/10.3989/scimar.2002.66s2157

Belcari P., Tserpes G., González M., et al. 2002. Distribution and abundance of Eledone cirrhosa (Lamarck, 1798) and Eledone moschata (Lamarck, 1798) (Cephalopoda: Octopoda) in the Mediterranean Sea. Sci. Mar. 66S2: 143-155. https://doi.org/10.3989/scimar.2002.66s2143

Bellodi A., Porcu C., Cannas R., et al. 2017. Life-history traits of the long-nosed skate Dipturus oxyrinchus. J. Fish Biol. 90: $867-888$. https://doi.org/10.1111/jfb.13205

Bertrand J.A., Gil De Sola L., Papaconstantinou C., et al. 2002. The general specifications of the MEDITS surveys. Sci. Mar. 66 (Suppl. 2): 9-17. https://doi.org/10.3989/scimar.2002.66s2

Bertrand J., Leonori I., Dremière P.Y., et al. 2002. Depth trajectory and performance of a trawl used for an international bot- tom trawl survey in the Mediterranean. Sci. Mar. 66(Suppl. 2): 169-182.

https://doi.org/10.3989/scimar.2002.66s2169

Biagi F., Sartor P., Ardizzone G.D., et al. 2002. Analysis of demersal fish assemblages of the Tuscany and Latium coasts (northwestern Mediterranean). Sci. Mar. 66(Suppl. 2): 233-242. https://doi.org/10.3989/scimar.2002.66s2233

Bitetto I., Facchini M.T., Spedicato M.T., et al. 2012. Spatial location of giant red shrimp (Aristaeomorpha foliacea, Risso,1827) in the central-southern Tyrrhenian Sea. Biol. Mar. Mediterr. 19: 92-95.

Bottari T., Busalacchi B., Jereb P., et al. 2004. Preliminary observation on the relationships between beak and body size in Eledone cirrhosa (Lamark, 1798) from the southern Tyrrhenian Sea. Biol. Mar. Mediterr. 11: 560-563.

Bottari T., Busalacchi B., Profeta A., et al. 2014. Elasmobranch distribution and assemblages in the southern Tyrrhenian Sea (Central Mediterranean). J. Aquac. Res. Development 5: 216. https://doi.org/10.4172/2155-9546.1000216

Brind'Amour A., Mérigot B., Ordines F., et al. 2016. Morphological traits measured for 89 fish species sampled in the Mediterranean Sea during MEDITS scientific surveys. SEANOE. https://doi.org/10.17882/41825

Brind'Amour A., Rochet M.J., Ordines F., et al. 2016. Environmental drivers explain regional variation of changes in fish and invertebrate functional groups across the Mediterranean Sea from 1994 to 2012. Mar. Ecol. Prog. Ser. 562: 19-35. https://doi.org/10.3354/meps11912

Busalacchi B., Rinelli P., De Domenico F., et al. 2010. Analysis of demersal fish assemblages off the southern Tyrrhenian Sea (Central Mediterranean). Hydrobiologia 654: 111-124. https://doi.org/10.1007/s10750-010-0374-9

Busalacchi B., Bottari T., Giordano D., et al. 2014. Distribution and biological features of the common pandora, Pagellus erythrinus (Linnaeus, 1758), in the southern Tyrrhenian Sea (Central Mediterranean). Helgol. Mar. Res. 68: 491-501. https://doi.org/10.1007/s10152-014-0404-5

Cannas R., Follesa M.C., Cabiddu S., et al. 2010. Molecular and morphological evidence of the occurrence of the Norwegian skate Dipturus nidarosiensis (Storm, 1881) in the Mediterranean Sea. Mar. Biol. Res. 6: 341-350. https://doi.org/10.1080/17451000903428496

Cannas R., Sacco F., Follesa M.C., et al. 2012. Genetic variability of the blue and red shrimp Aristeus antennatus in the Western Mediterranean Sea inferred by DNA microsatellite loci. Marine Ecology 33: 350-363. https://doi.org/10.1111/j.1439-0485.2011.00504.x

Cantafaro A., Ardizzone G.D., Enea M., Ligas A., et al. 2017. Assessing the importance of nursery area of European hake (Merluccius merluccius) using body condition index. Ecol. Indic. 81: 383-389. https://doi.org/10.1016/j.ecolind.2017.06.012

Capezzuto F., Maiorano P. Giove A., et al. 2004. Accrescimento, longevità ed effetti della senescenza in Aristeus antennatus nel Mar Ionio. Biol. Mar. Mediterr. 11: 114-123.

Capezzuto F., Carlucci R., Maiorano P., et al. 2009. Distribuzione spazio-temporale del reclutamento di Nephrops norvegicus (Linnaeus, 1758) nel Mar Ionio. Biol. Mar. Mediterr. 16: 190-193

Capezzuto F. Carlucci F., Maiorano P et al. 2010. The bathyal benthopelagic fauna in the NW Ionian Sea: structure, patterns and interactions. Chemistry \& Ecology. Vol. 26 Suppl.1: 199-217. https://doi oro/10.1080/02757541003639188

Carbonara P., Silecchia T., Zupa R., et al. 2006. Maturità e fecondità dello scampo Nephrops norvegicus (Linnaeus, 1758) nel Tirreno centro-meridionale. Biol. Mar. Med. 13: 827-830.

Carbonara P., Casciaro L., Bitetto I., et al. 2012. Reproductive cycle and length at first maturity of Trachurus trachurus in the Central-Western Mediterranean Seas. Biol. Mar. Mediterr. 19: 204-205.

Carbonara P., Intini S., Modugno E., et al. 2015. Reproductive biology characteristics of red mullet (Mullus barbatus L., 1758) in Southern Adriatic Sea and management implications. Aquat. Living Resour. 28: 21-31. https://doi.org/10.1051/alr/2015005

Carbonara P., Kolitari J., Đurović M., et al. 2017. The presence of Tetraodontidae species in the Central Mediterranean: an update from the southern Adriatic Sea. Acta Adriatica 58: 325 - 338 https://doi.org/10.32582/aa.58.2.11 
Carbonell A., Palmer M., Abelló P., et al. 2003. Mesoscale geographical patterns in the distribution of pandalid shrimps Plesionika spp. in the Western Mediterranean. Mar. Ecol. Prog. Ser. 247: 151-158. https://doi.org/10.3354/meps247151

Cariani A., Messinetti S., Ferrari A., et al. 2017. Improving the Conservation of Mediterranean Chondrichthyans: the ELASMOMED DNA barcode reference library. PLOS ONE 12: $\mathrm{e} 0170244$. https://doi.org/10.1371/journal.pone.0170244

Carlucci R., Capezzuto F., D’Onghia G. 2002. Aspetti della biologia di Lepidorhombus boscii (Risso, 1810) (Osteichthyes, Scophthalmidae) nel Mar Ionio. Biol. Mar. Mediterr. 9: 747-750.

Carlucci R., Capezzuto F., Maiorano P., et al. 2009. Distribution, population structure and dynamics of the black anglerfish (Lophius budegassa) (Spinola, 1987) in the Eastern Mediterranean Sea. Fish. Res. 95: 76-87. https://doi.org/10.1016/j.fishres.2008.07.015

Carlucci R., Capezzuto F., Sion L., et al. 2009. Aree di nursery di specie demersali nel mar Ionio settentrionale. Biol. Mar. Mediterr. 16: 194-196.

Carlucci R., Lembo G., Maiorano P. et al. 2009. Nursery areas of red mullet (Mullus barbatus), hake (Merluccius merluccius) and deep-water rose shrimp (Parapenaeus longirostris) in the Eastern-Central Mediterranean Sea. Est. Coast. Shelf Sci. 89: 529-538. https://doi.org/10.1016/j.ecss.2009.04.034

Carlucci R., Capezzuto F., Battista D., et al. 2010. Occurrence of juveniles of Scyliorhinus canicula and Mustelus mustelus in the north-western Ionian Sea. Biol. Mar. Mediterr. 17: 244-245.

Carpentieri P., Serpetti N., Colloca F., et al. 2016. Food preferences and rhythms of feeding activity of two co-existing demersal fish, the longspine snipefish, Macroramphosus scolopax (Linnaeus, 1758), and the boarfish Capros aper (Linnaeus, 1758), on the Mediterranean deep shelf. Mar. Ecol. 37: 106-118. https://doi.org/10.1111/maec.12265

Cartes J.E., Abelló P., Lloris D., et al. 2002. Feeding guilds of western Mediterranean demersal fish and crustaceans: an analysis based on a spring survey. Sci. Mar. 66: 209-220. https://doi.org/10.3989/scimar.2002.66s2209

Cartes J.E., Rey J., Lloris D., et al. 2004. Influence of environmental variables on the feeding and diet of European hake (Merluccius merluccius) on the Mediterranean Iberian coasts. J. Mar. Biol. Assoc. U.K. 84(4): 831-835. https://doi.org/10.1017/s0025315404010021h

Cartes J.E., Maynou F., Lloris D., et al. 2009. Influence of trawl type on the composition and diversity of deep benthopelagic fish and decapod assemblages off the Catalan coasts (western Mediterranean). Sci. Mar. 73(4): 725-737. https://doi.org/10.3989/scimar.2009.73n4725

Cartes J.E., Maynou F., Abelló P., et al. 2011. Long-term changes in the abundance and deepening of the deep-sea shrimp Aristaeomorpha foliacea in the Balearic Basin: Relationships with hydrographic changes at the Levantine Intermediate Water. J. Mar. Syst. 88: 516-525. https://doi.org/10.1016/j.jmarsys.2011.07.001

Cartes J.E., Fanelli E., Kapiris K., et al. 2014. Spatial variability in the trophic ecology and biology of the deep-sea shrimp Aristaeomorpha foliacea in the Mediterranean Sea. Deep-Sea Res. I 87: 1-13. https://doi.org/10.1016/j.dsr.2014.01.006

Casadevall M., Torres J., El Aoussimi A., et al. 2016. Pollutants and parasites in bycatch teleosts from southeastern Spanish Mediterranean's fisheries: Concerns relating the foodstuff harnessing. Mar. Pollut. Bull. 104: 182-189. https://doi.org/10.1016/j.marpolbul.2016.01.040

Casciaro L., Gaudio P., Bitetto I., et al. 2015. Catch structure and reproductive pattern of Melicertus kerathurus in the South-West Adriatic Sea. Biol. Mar. Mediterr. 22: 162-163.

Cau A., Carbonell A., Follesa M.C., et al. 2002. MEDITS-based information on the deep water red shrimps Aristaeomorpha foliacea and Aristeus antennatus (Crustacea: Decapoda: Aristeidae). Sci. Mar. 66(Suppl. 2): 103-124 https://doi.org/10.3989/scimar.2002.66s2103

Cavanna P., Lanteri L., Beccornia E., et al. 2008. Accrescimento di Illex coindetii (Verany, 1839) e Todaropsis eblanae (Ball, 1841) in Mar Ligure. Biol. Mar. Mediterr. 15: 320-321.

Ceriola L., Marano C. A., Martino M., et al. 2004. Informazioni preliminari sull'accrescimento di Trigla lucerna Linnaeus, 1758 nell'Adriatico meridionale. Biol. Mar. Mediterr. 11: 163-165.
Ceriola L., Marano C. A., Martino M., et al. 2006. Abbondanza e densità di alcuni cefalopodi Teuthoidea nell'Adriatico Meridionale. Biol. Mar. Mediterr. 13: 844-847.

Ceriola L., Ungaro N., Toteda F. 2006. Some information on the biology of Illex coindetii Verany, 1839 (Cephalopoda, Ommastrephidae) in the South-Western Adriatic Sea (Central Mediterranean). Fish. Res. 82: 41-49. https://doi.org/10.1016/j.fishres.2006.08.024

Ceriola L., Ungaro N., Toteda F. 2007. A "Traffic" Light approach for the assessment of the Broadtail shortfin squid Illex coindetii Verany, 1839 in the Southern Adriatic Sea (Central Mediterranean). Rev. Fish Biol. Fish. 17: 145-157. https://doi.org/10.1007/s11160-006-9019-5

Ceriola L., Accadia P., Mannini P., et al. 2008 A bio-economic indicators suite for the appraisal of the demersal trawl fishery in the Southern Adriatic Sea (Central Mediterranean). Fish. Res. 92: $255-267$ https://doi.org/10.1016/j.fishres.2008.01.017

Chimienti G., Maiorano P., Mastrototaro F. 2015. Pennatula rubra facies in the Ionian Sea (Central Mediterranean). Biol. Mar. Mediterr. 22: 76-80.

Ciavaglia E., Manfredi C., Di Silverio M.C., et al. 2006. Serie storiche e biologia di Trisopterus minutus capelanus (Lacepede, 1800) in Alto e Medio Adriatico. Biol. Mar. Mediterr. 13: $210-214$.

Coelho R., Rey J., Gil de Sola L., et al. 2010. Comparing Atlantic and Mediterranean populations of the velvet belly lantern shark, Etmopterus spinax, with comments on the efficiency of density-dependent compensatory mechanisms. Mar. Biol. Res. 6: 373-380. https://doi.org/10.1080/17451000903300885

Coll M., Santojanni A., Palomera I., et al. 2007. An ecological model of the Northern and Central Adriatic Sea: analysis of the ecosystem structure and fishing impacts. J. Mar. Syst. 67: $119-154$. https://doi.org/10.1016/j.jmarsys.2006.10.002

Colloca F., Maiorano L., Carpentieri P., et al. 2006. Hake abundance and nurseries in the Ligurian and Tyrrhenian Seas (GSA 9): from 1985 to 2003. Biol. Mar. Mediterr. 13: 219-222.

Colloca F., Bartolino V., Lasinio G.J., et al. 2009. Identifying fish nurseries using density and persistence measures. Mar. Ecol. Prog. Ser. 381: 287-296. https://doi.org/10.3354/meps07942

Colloca F., Mastrantonio G., Jona Lasinio G., et al. 2014. Parapenaeus longirostris (Lucas, 1846) an early warning indicator species of global warming in the central Mediterranean Sea. J. Marine Syst. 138: 29-39. https://doi.org/10.1016/j.jmarsys.2013.10.007

Colloca F., Garofalo G., Bitetto I., et al. 2015. The seascape of demersal fish nursery areas in the North Mediterranean Sea, a first step towards the implementation of spatial planning for trawl fisheries. PLoS ONE 10: e0119590. https://doi.org/10.1371/journal.pone.0119590

Colloca F., Enea M., Ragonese S., et al. 2017. A century fishery data documenting the collapse of smooth-hounds (Mustelus spp.) in Mediterranean Sea. Aquat. Conserv. Mar. Freshw. Ecosyst. 27: 1145-1155. https://doi.org/10.1002/aqc.2789

Consoli P., Romeo T., Rinelli P. 2004. The sexual regime of deepwater shrimps (Decapoda, Pandalidae) in the southern Tyrrhenian Sea (Central Mediterranean). Crustaceana 77: 751-756. https://doi.org/10.1163/1568540041958581

Corrales X., Coll M., Tecchio S., et al. 2015. Ecosystem structure and fishing impacts in the northwestern Mediterranean Sea using a food web model within a comparative approach. J. Mar. Syst. 148: 183-199. https://doi.org/10.1016/j.jmarsys.2015.03.006

Cotter J., Petitgas P., Abella A., et al. 2009. Towards an ecosystem approach to fisheries management (EAFM) when trawl surveys provide the main source of information. Aquat. Living Resour. 22: 243-254. https://doi.org/10.1051/alr/2009025

Courbin N., Fablet R., Mellon-Duval C., et al. 2007. Are hake otolith macrostructures randomly deposited? Insights from an unsupervised statistical and quantitative approach applied to Mediterranean hake otoliths. ICES J. Mar. Sci. 64: 1191-1201. https://doi.org/10.1093/icesims/fsm083

Cresson P., Fabri M.-C., Bouchoucha M., et al. 2014. Mercury in organisms from the Northwestern Mediterranean slope: Importance of food sources. Sci. Total Environ. 497: 229-238. 
https://doi.org/10.1016/j.scitotenv.2014.07.069

Cresson P., Fabri M-C., Miralles F.M. et al. 2016. Variability of PCB burden in 5 fish and sharks species of the French Mediterranean continental slope. Environ. Pollut. 212: 374-381. https://doi.org/10.1016/j.envpol.2016.01.044

Cuccu D., Jereb P., Ragonese S., et al. 2009. On the abundance and spatial distribution of Illex coindetii (Cephalopoda: Ommastrephidae) and Eledone moschata (Cephalopoda: Octopodidae) in the Sardinian Seas (central-western Mediterranean). A preliminary and qualitative investigation with special attention to some environmental constraints. Boll. Malacol. 45 (suppl.): 102-109.

Cuccu D., Mereu M., Cannas R., et al. 2009. Variability in Sepietta oweniana (Cephalopoda: Sepiolidae) hectocotyli. Ital. J. Zool. 76: 189-193. https://doi.org/10.1080/11250000802346241

Cuccu D., Mereu M., Follesa M.C., et al. 2011. Bathypolypus sponsalis (Cephalopoda: Octopoda) from the central western Mediterranean Sea. J. Mar. Biol. Assoc. U. K. 91: 549-553. https://doi.org/10.1017/S0025315409000976

Čustović S., Vrgoč N., Isajlović I., et al. 2015. Distribution and population structure of greater weever, Trachinus draco (Linnaeus, 1758.), in the Northern and Central Adriatic Sea. Naše more 62 : 20-24 https://doi.org/10.17818/NM.1.4.2015

D’Onghia G., Sion L., Maiorano P., et al. 2006. Population biology and life strategies of Chlorophthalmus agassizii Bonaparte, 1840 (Pisces: Osteichthyes) in the Mediterranean Sea. Mar. Biol. 149: 435-446. https://doi.org/10.1007/s00227-005-0231-y

D’Onghia G., Maiorano P., Sion L. 2008. A review on the reproduction of grenadiers in the Mediterranean with new data on the gonad maturity and fecundity. In Alexei M. Orlov T. Iwamoto (eds), Grenadiers of the World Oceans: Biology, Stock Assessment and Fisheries". American Fisheries Society Symposium, 63: 169-184.

D’Onghia G., Giove A., Maiorano P., et al. 2012. Exploring relationships between demersal resources and environmental factors in the Ionian Sea (Central Mediterranean). J. Mar. Biol. 2012: 279406. https://doi.org/10.1155/2012/279406

De Madron X., Ferre B., Le Corre G., et al. 2005. Trawling-induced resuspension and dispersal of muddy sediments and dissolved elements in the Gulf of Lion (NW Mediterranean). Cont. Shelf Res. 25: 2387-2409. https://doi.org/10.1016/j.csr.2005.08.002

Deudero S., Alomar C. 2015. Mediterranean marine biodiversity under threat: Reviewing influence of marine litter on species. Mar. Pollut. Bull. 98: 58-68. https://doi.org/10.1016/j.marpolbul.2015.07.012

Dimech M., Camilleri M., Hiddink J.G., et al. 2008. Differences in demersal community structure and biomass size spectra within and outside the Maltese Fishery Management Zone (FMZ). Sci. Mar. 72: 669-682.

https://doi.org/10.3989/scimar.2008.72n4669

Dimech M., Kaiser M.J., Ragonese S., et al. 2012. Ecosystem effects of fishing on the continental slope in the Central Mediterranean Sea. Mar. Ecol. Progr. Ser. 449: 41-54. https://doi.org/10.3354/meps09475

Dogrammatzi A., Karachle P.K. 2015. First record of the antenna codlet Bregmaceros atlanticus. Mediterr. Mar. Sci. 16: 266-284. https://doi.org/10.12681/mms.1292

Donnaloia M., Gaudio P., Bitteto I., et al. 2010. Sexual maturity of the horned octopus Eledone cirrhosa (Lamarck, 1798). Biol. Mar. Mediterr. 17: 336-337.

Druon J.-N., Fiorentino F., Murenu M., et al. 2015. Modelling of European hake nurseries in the Mediterranean Sea: an ecological niche approach. Prog. Oceanogr. 130: 188-204. https://doi.org/10.1016/j.pocean.2014.11.005

Durrieu De Madron X., Ferre B., Le Corre G., et al. 2005. Trawlinginduced resuspension and dispersal of muddy sediments and dissolved elements in the Gulf of Lion (NW Mediterranean). Cont. Shelf Res. 25: 2387-2409. https://doi.org/10.1016/j.csr.2005.08.002

Fabri M-C., L. Pedel L., Beuck L., et al. 2013. Megafauna of vulnerable marine ecosystems in French Mediterranean submarine canyons: Spatial distribution and anthropogenic impacts. DeepSea Res. Pt. II 104: 184-207. https://doi.org/10.1016/j.dsr2.2013.06.016

Fanelli E., Cartes J.E. 2004. Feeding habits of Pandalid shrimps in the Alboran Sea (SW Mediterranean): Influence of bio- logical and environmental variables. Mar. Ecol. Prog. Ser. 280: 227-238.

https://doi.org/10.3354/meps280227

Fanelli E., Colloca F., Belluscio A., et al. 2004. Distribution characteristics of pandalid shrimps (Decapoda: Caridea: Pandalidae) along the Central Mediterranean Sea. Mediter. Mar. Sci. 5: $35-43$ https://doi.org/10.12681/mms.201

Fanelli E., Rey J., Torres P., et al. 2009. Feeding habits of blackmouth catshark Galeus melastomus Rafinesque, 1810 and velvet belly lantern shark Etmopterus spinax (Linnaeus, 1758) in the western Mediterranean. J. Appl. Ichthyol. 25 (Suppl. 1): 83-93. https://doi.org/10.1111/j.1439-0426.2008.01112.x

Farias C., Ordines F., García-Ruiz C., et al. 2016. Protogrammus alboranensis $\mathrm{n}$. sp. (Teleostei: Callionymidae), a new species of dragonet from the Alboran Sea, western Mediterranean Sea. Sci. Mar. 80(1): 51-56. https://doi.org/10.3989/scimar.04340.13A

Farré M., Tuset V.M., Cartes J.E., et al. 2016. Depth-related trends in morphological and functional diversity of demersal fish assemblages in the western Mediterranean Sea. Prog. Oceanogr. 147: $22-37$ https://doi.org/10.1016/j.pocean.2016.07.006

Farriols M.T., Ordines F., Hidalgo M., et al. 2015. N90 index: A new approach to biodiversity based on similarity and sensitive to direct and indirect fishing impact. Ecol. Indic. 52: 245-255. https://doi.org/10.1016/j.ecolind.2014.12.009

Farriols M.T., Ordines F., Somerfield P.J., et al. 2017. Bottom trawl impacts on Mediterranean demersal fish diversity: Not so obvious or are we too late? Cont. Shelf Res. 137: 84-102 https://doi.org/10.1016/j.csr.2016.11.011

Fernández A.M., Lloris D., Pérez J.L., et al. 2012. On the occurrence of Zenopsis conchifer (Lowe, 1852) (Osteichthyes, Zeidae) in the Mediterranean Sea. Arxius Misc. Zool. 10: 50-54. https://doi.org/10.32800/amz.2012.10.0050

Ferraton F., Harmelin V.M., Mellon-Duval C., et al. 2007. Spatiotemporal variation in diet may affect condition and abundance of juvenile European hake in the Gulf of Lions (NW Mediterranean). Mar. Ecol. Prog. Ser. 336: 197-208. https://doi.org/10.3354/meps337197

Finotto L., Gristina M., Garofalo G., et al. 2015. Contrasting life history and reproductive traits in two populations of Scyliorhinus canicula. Mar. Biol. 162: 1175-1186. https://doi.org/10.1007/s00227-015-2659-Z

Fiorentino F., Garofalo G., De Santi A. et al. 2003. Spatio-temporal distribution of recruits (0 group) of Merluccius merluccius and Phycis blennoides (Pisces, Gadiformes) in the Strait of Sicily (Central Mediterranean) Hydrobiologia 503: 223-236 https://doi.org/10.1023/B:HYDR.0000008485.85468.ef

Fiorentino F., Garofalo G., Gristina M., Levi D. 2003. The ratio between "bottom dwelling" and overall fish biomass (BOI) as an indicator of trawling impact on demersal assemblages. Biol. Mar. Mediterr. 10: 819-823.

Fiorentino F., Camilleri M., Gancitano S., et al. 2005. On the presence of Pomadasys incisus, Bowdich, 1825, (Ostheichthyes, Haemulidae) in Maltese coastal waters (Strait of Sicily-central mediterranean). Biol. Mar. Mediterr. 12: 514-516.

Fiorentino F., Badalamenti F., D'Anna G., et al. 2008. Changes in spawning-stock structure and recruitment pattern of red mullet, Mullus barbatus, after a trawl ban in the Gulf of Castellammare (central Mediterranean Sea). ICES J. Mar. Sci. 65: 1175-1183. https://doi.org/10.1093/icesjms/fsn104

Fiorentino F., Gancitano V., Giusto G.B., et al. 2015. Marine litter on trawlable bottoms of the Strait of Sicily. Biol. Mar. Mediterr. 22: $225-228$.

Fiorentino F., Patti B., Colloca F., et al. 2013. A comparison between acoustic and bottom trawl estimates to reconstruct the biomass trends of sardine and anchovy in the Strait of Sicily (Central Mediterranean). Fish. Res. 147: 290- 295. https://doi.org/10.1016/j.fishres.2013.06.001

Florio G., Consoli P., Perdichizzi F., et al. 2003. Annotated checklist of the skates (Chondrichthyes, Rajidae) in the South-Tyrrhenian Sea from Cape Suvero (Calabria) to Cape San Vito (Sicily). Biol. Mar. Mediterr. 10: 824-827.

Follesa M.C., Cabiddu S., Gastoni A., et al. 2007. On the reproductive biology of the deep-sea lobster, Polycheles typhlops (Decapoda, Palinura, Polychelidae), from the central-western Mediterranean. Crustaceana 80: 839-846. https://doi.org/10.1163/156854007781363060 
Follesa M.C., Cannas, R., Gastoni A., et al. 2008. Abnormal rostrum in Polycheles typhlops Heller, 1862 (Decapoda: Polychelidae) from the central western mediterranean. J. Crustac. Biol. 28: 731-734. https://doi.org/10.1651/08-2987.1

Follesa M.C., Porcu C., Gastoni A., et al. 2009. Community structure of bathyal decapod crustaceans off South-Eastern Sardinian deep-waters (Central-Western Mediterranean). Mar. Ecol. 30 (Suppl. 1): 188-199. https://doi.org/10.1111/j.1439-0485.2009.00323.x

Follesa M.C., Mulas A., Cabiddu S., et al. 2010. Diet and feeding habits of two skate species, Raja brachyura and Raja miraletus (Chondrichthyes, Rajidae) in Sardinian waters (central-western Mediterranean). Ital. J. Zool. 77: 53-60 https://doi.org/10.1080/11250000802589600

Follesa M.C., Porcu C., Cabiddu S., et al. 2011. Deep-water fish assemblages in the central-western Mediterranean (south Sardinian deep-waters). J. Appl. Ichthyol. 27: 129-135. https://doi.org/10.1111/j.1439-0426.2010.01567.x

Follesa M.C., Cannas R., Cabiddu S., et al. 2012. Preliminary observations of the reproductive biology and diet for the Norwegian skate Dipturus nidarosiensis (Rajidae) from the Central Western Mediterranean Sea. Cybium 36: 473-477. https://doi.org/10.26028/cybium/2012-363-006

Fortibuoni T., Bahri T., Camilleri M., et al. 2010. Nursery and spawning areas of deep-water rose shrimp, Parapenaeus longirostris (Decapoda: Penaidae), in the Strait of Sicily (Central Mediterranean Sea). J. Crustac. Biol. 30:167-174. https://doi.org/10.1651/09-3167.1

Fricke R., Ordines F. 2017. First record of the Alboran dragonet, Protogrammus alboranensis (Actinopterygii: Callionymiformes: Callionymidae), from the Balearic Islands (western Mediterranean). Acta Ichthyol. Piscat. 47: 289-295. https://doi.org/10.3750/AIEP/02280

Fricke R., Ordines F. 2017. First record of the reticulated dragonet, Callionymus reticulatus Valenciennes, 1837 (Actinopterygii: Callionymiformes: Callionymidae), from the Balearic Islands, western Mediterranean. Acta Ichthyol. Piscat. 47: 163-171. https://doi.org/10.3750/AIEP/02098

Frodella N., Cannas R., Velonà A., et al. 2016. Population connectivity and phylogeography of the Mediterranean endemic skate Raja polystigma and evidence of its hybridization with the parapatric sibling $R$. montagui. Mar. Ecol. Prog. Ser. 554: 99-113. https://doi.org/10.3354/meps 11799

Gaertner J.C., Bertrand J., Souplet A. 2002. STATIS-CoA: A methodological solution to assess the spatio-temporal organization of species assemblages. Application to the demersal assemblages of the French Mediterranean Sea. Sci. Mar. 66(Suppl. 2): $221-232$ https://doi.org/10.3989/scimar.2002.66s2221

Gaertner J.C., Bertrand A., Gil de Sola L., et al. 2005. Large spatial scale variation of demersal fish assemblage structure on the continental shelf of the NW Mediterranean Sea. Mar. Ecol. Prog. Ser. 297: 245-257. https://doi.org/10.3354/meps297245

Gaertner J.C., Bertrand J.A., Samani D., et al. 2005. Spatio-temporal organization of demersal assemblages of the East Corsica (Mediterranean Sea). Vie Milieu 55: 81-89. https://archimer.ifremer.fr/doc/2005/publication-692.pdf

Gaertner J.C., Bertrand J.A., Relini G., et al. 2007. Spatial pattern in species richness of demersal fish assemblages on the continental shelf of the northern Mediterranean Sea: a multiscale analysis. Mar. Ecol. Prog. Ser. 341: 191-203. https://doi.org/10.3354/meps341191

Gaertner J.C, Mérigot B., Relini G., et al. 2010. Reproducibility of the multi-component aspect of species diversity across different areas and scales: towards the constitution of a shortlist of complementary indices for monitoring fish diversity? Ecography 33: 1123-1135. https://doi.org/10.1111/j.1600-0587.2009.06259.x

Gaertner J.C., Maiorano P., Mérigot B., et al. 2013. Large-Scale diversity of slope fishes: pattern inconsistency between multiple diversity indices. PLoS ONE 8: e66753. https://doi.org/10.1371/journal.pone.0066753

Gaglio G., Bottari T., Rinelli P., et al. 2011. Prevalence of Clavella stellata (Copepoda: Lernaeopodidae) (Kroyer 1838) in the European hake (Merluccius merluccius) (L. 1758) in South Tyrrhenian Sea (Central Mediterranean). J. Appl. Ichthyol. 27: 136-138.

https://doi.org/10.1111/j.1439-0426.2010.01526.x
Gancitano V., Badalucco C., Gancitano S., et al. 2008. Potenzialità produttive e stato di sfruttamento di Parapenaeus longirostris (Lucas,1846) (Crustacea; Decapoda) nello Stretto di Sicilia (GSA 16). Biol. Mar. Mediterr. 15: 324-325.

Gancitano V., Cusumano S., Giusto G.B., et al. 2008. Valutazione dello stato di sfruttamento del gambero rosso Aristaeomorpha foliacea (Risso, 1827) (Crustacea; Decapoda) nello Stretto di Sicilia. Biol. Mar. Mediterr. 15: 326-327.

Gancitano V., Badalucco C., Cusumano S., et al. 2013. Exploitation state of Black-bellied Angler, Lophius budegassa (Spinola, 1807) (Pisces: Lophiidae), in the Strait of Sicily (GSA 15\&16). Biol. Mar. Mediterr. 20: 184-185.

Gancitano V., Enea M., Colloca F., et al. 2015. Temporal dynamics of demersal resources in the south of Sicily (GSA 16) during the last twenty years. Biol. Mar. Mediterr. 22: 166-167.

Gancitano V., Giusto G.B., Labanchi L., et al. 2017. Catture, sforzo di pesca ed abbondanza di pesce sciabola, L. caudatus (Euphrasen, 1788) nello Stretto di Sicilia. Biol. Mar. Mediterr. 24: 186-187.

García Raso J.E., Salmerón F., Baro J., et al. 2014. The tropical African hermit crab Pagurus mbizi (Crustacea, Decapoda, Paguridae) in the Western Mediterranean Sea: a new alien species or filling gaps in the knowledge of the distribution? Mediterr. Mar. Sci., 15(1): 172-178. https://doi.org/10.12681/mms.530

García-Rivera S., Sánchez Lizaso J.L., Bellido Millán J.M. 2017. Composition, spatial distribution and sources of macro-marine litter on the Gulf of Alicante seafloor (Spanish Mediterranean). Mar. Pollut. Bull. 121: 249-259. https://doi.org/10.1016/j.marpolbul.2017.06.022

García-Rodríguez M., Abelló P., Fernández A., et al. 2011. Demersal assemblages on the Soft Bottoms off the Catalan-Levante of the Spanish Mediterranean. J. Mar. Biol. 2011: 976396. https://doi.org/10.1155/2011/976396

García-Rodríguez M., Fernández A., Esteban A. 2011. Biomass response to environmental factors in two congeneric species of Mullus, Mullus barbatus and Mullus surmuletus, off CatalanoLevantine Mediterranean coast of Spain: a preliminary approach. Anim. Biodiv. Conserv. 34: 113-122.

García-Rodríguez M., Pereda P., Landa J., et al. 2005. On the biology and growth of the angler fish Lophius budegassa Spinola, 1807 in the Spanish Mediterranean: a preliminary approach. Fish. Res. 71: 197-208. https://doi.org/10.1016/j.fishres.2004.08.033

García-Ruiz C., Lloris D., Rueda J.L., et al. 2015. Spatial distribution of ichthyofauna in the northern Alboran Sea (Western Mediterranean). J. Nat. Hist. 49: 1191-1224. https://doi.org/10.1080/00222933.2014.1001457

Gargano F., Garofalo G., Fiorentino F. 2017. Exploring connectivity between spawning and nursery areas of Mullus barbatus (L., 1758) in the Mediterranean through a dispersal model. Fish. Oceanogr. 26: 476-497. https://doi.org/10.1111/fog.12210

Garofalo G., Gristina M., Fiorentino F., et al. 2003. Distributional pattern of rays (Pisces, Rajidae) in the Strait of Sicily in relation to fishing pressure. Hydrobiologia 503: 245-250. https://doi.org/10.1007/978-94-017-2276-6 25

Garofalo G., Fiorentino F., Bono G., et al. 2004. Identifying spawning and nursery areas of Red mullet (Mullus barbatus, L., 1758) in the Strait of Sicily. In: Nishida T., Kailola P.J., Hollingworth C.E. (eds), GIS/Spatial Analyses in Fishery and Aquatic Sciences, (Vol. 2). Fishery-aquatic GIS Research Group, Saitama, Japan, pp.101-110.

Garofalo G., Gristina M., Toccaceli M., et al. 2004. Geostatistical modelling of biocenosis distribution in the Strait of Sicily. In: Nishida T., Kailola P.J., Hollingworth C.E. (eds.), GIS/Spatial Analyses in Fishery and Aquatic Sciences, (Vol. 2). Fisheryaquatic GIS Research Group, Saitama, Japan, pp.241-250.

Garofalo G., Fiorentino F., Gristina M., et al. 2007. Stability of spatial pattern of fish species diversity in the Strait of Sicily (central Mediterranean). Hydrobiologia 580:117-124. https://doi.org/10.1007/978-1-4020-6156-1_10

Garofalo G., Ceriola L., Gristina M., et al. 2010. Nurseries, spawning grounds and recruitment of Octopus vulgaris in the Strait of Sicily, central Mediterranean Sea. ICES J. Mar. Sci. 67: 1363-1371. https://doi.org/10.1093/icesjms/fsq101

Garofalo G., Fortibuoni T., Gristina M., et al. 2011. Persistence and co-occurrence of demersal nurseries in the Strait of Sicily (Central Mediterranean): implications for fishery management. 
J. Sea Res. 66: 29-38 https://doi.org/10.1016/j.seares.2011.04.008

Garofalo G., Fezzani S., Gargano F., et al. 2017. Predictive distribution models of European hake in the south-central Mediterranean Sea. Hydrobiologia 821: 153-172 https://doi.org/10.1007/s10750-017-3338-5

Garoia F, Guarniero I, Ramsak A, et al. 2004. Microsatellite DNA variation reveals high gene flow and panmictic populations in the Adriatic shared stocks of the European squid and cuttlefish (Cephalopoda). Heredity 93: 166-174. https://doi.org/10.1038/sj.hdy.6800489

Garoia F., Guarniero I., Piccinetti C., et al. 2004. First microsatellite loci of red mullet (Mullus barbatus) and their application to genetic structure analysis of Adriatic shared stock. Mar. Biotechnol. 6: 446-452. https://doi.org/10.1007/s10126-004-3045-x

Giordano D., Bottari T., Busalacchi B., et al. 2005. On the relationship between beaks and body size in Sepia officinalis from the Southern Tyrrhenian Sea (Central Mediterranean). Cah. Biol. Mar. 46: 35-41.

Giordano D., Bottari T., Rinelli P. 2005. Cephalopod assemblages caught by trawling along the Southern Tyrrhenian Sea (Central Mediterranean). Iberus 23: 33-42.

Giordano D., Perdichizzi A., Pirrera L., et al. 2009. Distribution and biology of Sepietta oweniana (Pfeffer, 1908) (Sepiolodae: Cephalopoda) in the Southern Tyrrhenian Sea (Central Mediterranean). Cah. Biol. Mar. 50: 1-10.

Giordano D., Bottari T., Perdichizzi A., et al. 2010. Distribution and some aspects of the biology of Scaeurgus unicirrhus (Cephalopoda: Octopodidae) in the Southern Tyrrhenian Sea (Central Mediterranean). Vie Milieu 60: 291-297.

Giordano D., Busalacchi B., Bottari T., et al. 2010. Population dynamics and distribution of Eledone cirrhosa (Lamarck, 1798) in the Southern Tyrrhenian Sea (Central Mediterranean). Cah. Biol. Mar. 51: 213-227.

Giove M., Minerva P., Maiorano G. et al. 2010. Elasmobranch assemblages in the Ionian Sea. Biol. Mar. Mediterr. 17: 250-251.

Goñi R., S. Adlerstein, F. Alvarez, M. et al. 2004. Recruitment indices of European hake, Merluccius merluccius (Linnaeus 1758), in the Northwest Mediterranean based on landings from bottom-trawl multispecies fisheries. ICES J. Mar. Sci. 61: 760-773. https://doi.org/10.1016/j.icesjms.2004.04.002

González M., Sánchez P. 2002. Cephalopod assemblages caught by trawling along the Iberian Peninsula Mediterranean coast. Sci. Mar. 66: 199-208. https://doi.org/10.3989/scimar.2002.66s2199

Gouraguine A., Hidalgo M., Moranta J., et al. 2011. Elasmobranch spatial segregation in the western Mediterranean. Sci. Mar. 75: 653-664. https://doi.org/10.3989/scimar.2011.75n4653

Granger V., Bez N., Fromentin J.-M., et al. 2015. Mapping diversity indices: not a trivial issue. Methods Ecol. Evol. 6: 688-696. https://doi.org/10.1111/2041-210X.12357

Granger V., Fromentin J.M., Bez N., et al. 2015. Large-scale spatiotemporal monitoring highlights hotspots of demersal fish diversity in the Mediterranean Sea. Prog. Oceanogr. 130: 65-74. https://doi.org/10.1016/j.pocean.2014.10.002

Granzotto A., Fiorentino F., Garofalo G., et al. 2006. Un approccio trofico allo studio della comunità dei pesci demersali dello Stretto di Sicilia nell' analisi della serie temporale 1994-2004. Biol. Mar. Mediterr. 13: 250-252.

Gristina M., Garofalo G., Giusto G.B., et al. 2002. A comparative study on hake length structures derived from trawl surveys and commercial catches in the Strait of Sicily. Biol. Mar. Mediterr. 9: 758-762.

Gristina M., Bono G., Fiorentino F., et al. 2003. L'impatto della pesca a strascico sulla diversità delle comunità demersali dello Stretto di Sicilia. Biol. Mar. Mediterr. 10: 838-842

Gristina M., Garofalo G., Bianchini M.L., et al. 2004. Evaluating the performance of an index of trawling impact in the Strait of Sicily. Biol. Mar. Mediterr. 11: 230-241.

Gristina M., Bahri T., Fiorentino F., et al. 2006. Comparison of demersal fish assemblages in three areas of the Strait of Sicily under different trawling pressure. Fish. Res. 81: 60-71. https://doi.org/10.1016/j.fishres.2006.05.010

Gristina M., Fiorentino F., Garofalo G., et al. 2006. Trend temporale nella comunità demersale di piattaforma e di scarpata nello Stretto di Sicilia (1994-2004). Biol. Mar. Mediterr. 13: 253-256.

Gristina M., Fiorentino F., Gancitano V., et al. 2013. The role of juveniles in structuring demersal assemblages in trawled fishing grounds. Est. Coast. Shelf Sci. 133: 78-87. https://doi.org/10.1016/jecss.2013.08.014

Guerao G., Abelló P. 2007. The first zoea of Inachus aguiarii, Inachus communissimus and Ergasticus clouei (Decapoda, Brachyura, Majoidea) with implications for the systematics of the family Inachidae. Zootaxa 1429: 55-68. https://doi.org/10.1163/001121610x520975

Guerao G., Rufino M.M., Abelló P. 2002. The complete larval development and first juvenile of the spider crab Inachus thoracicus Roux, 1830 (Brachyura: Majidae: Inachinae). J. Plankton Res. 24(9): 875-887. https://doi.org/10.1093/plankt/24.9.875

Guerao G., Rufino M.M., Abelló P. 2003. Morphology of the larval and first juvenile stages of the spider crab Lissa chiragra (Brachyura: Majidae: Pisinae). J. Nat. Hist. 37: 647-671. https://doi.org/10.1080/00222930110116048

Guerao G., Abelló P., Díaz D. 2005. The complete larval development of the crab Pilumnus spinifer (Brachyura: Xanthoidea: Pilumnidae) reared in the laboratory. J. Nat. Hist. 39(35): 3187-3216. https://doi.org/10.18353/crustacea.40.0_57

Guerao G., Díaz D., Abelló P. 2006. Morphology of puerulus and early juvenile stages of the spiny lobster Palinurus mauritanicus (Decapoda: Palinuridae). J. Crustac. Biol. 26(4): 480-494 https://doi.org/10.1651/c-2615.1

Guijarro B., Massutí E., Moranta J., et al. 2008. Population dynamics of the red-shrimp Aristeus antennatus in the Balearic Islands (western Mediterranean): spatio-temporal differences and influence of environmental factors. J. Mar. Syst. 71: 385-402. https://doi.org/10.1016/j.jmarsys.2007.04.003

Guijarro B., Massutí E., Moranta J., et al. 2009. Short spatio-temporal variations in the population dynamics and biology of the deep-water rose shrimp Parapenaeus longirostris (Decapoda: Crustacea) in the western Mediterranean. Sci. Mar. 73: 183-197. https://doi.org/10.3989/scimar.2009.73n1183

Guijarro B., Tserpes G., Moranta J., et al. 2011. Assessment of the deep water trawl fishery off the Balearic Islands (western Mediterranean): from single to multi-species approach. Hydrobiologia 670: $67-85$. https://doi.org/10.1007/s10750-011-0670-z

Guijarro B., Fanelli E., Moranta J., et al. 2012. Small-scale differences in the distribution and population dynamics of pandalid shrimps in the western Mediterranean in relation to environmental factors. Fish. Res. 119-120: 33-47. https://doi.org/10.1016/j.fishres.2011.12.00

Guijarro B., Massutí E. Quetglas A, et al. 2012 Inter- and intra-annual trends and status indicators of nektobenthic elasmobranch populations off the Balearic Islands (north-western Mediterranean). Sci. Mar. 76: 87-96. https://doi.org/10.3989/scimar.03432.22A

Jereb P., Cuccu D., Giordano D., et al. 2005. Uso delle serie storiche di campagne sperimentali a strascico per lo studio dei Cefalopodi: un nuovo metodo di analisi esplorativa. Biol. Mar. Mediterr. 12: 526-530.

Jereb P., Cuccu D., Giordano D., et al. 2005. Using historical series of trawl surveys data to investigate cephalopods: a new method of exploratory analysis. Biol. Mar. Mediterr. 12: 526-530.

Harmelin V.M., Mahe K., Bodiguel X., et al. 2012. Possible link between prey quality, condition and growth of juvenile hake (Merluccius merluccius) in the Gulf of Lions (NW Mediterranean). Cybium 36: 323-328. https://doi.org/10.26028/cybium/2012-362-001

Hidalgo M., Massutí E., Guijarro B., et al. 2009. Population effects and changes in life history traits in relation to phase transitions induced by long-term term fishery harvesting: European hake (Merluccius merluccius L.) off the Balearic Islands. Can. J. Fish. Aquat. Sci. 66: 1355-1370. https://doi.org/10.1139/F09-08

Hidalgo M., Rouyer T., Bartolino V., et al. 2012. Context-dependent interplays between truncated demographies and climate variation shape the population growth rate of a harvested species. Ecography 35: 637-649. https://doi.org/10.1111/j.1600-0587.2011.07314 x

Hidalgo M., Quetglas A., Ordines F., et al. 2017. Size-spectra across geographical and bathymetric gradients reveal contrasting resilient mechanisms of recovery between Atlantic and Mediterranean fish communities. J. Biogeogr. 44: 1939-1951. https://doi.org/10.1111/jbi.12976

Holcer D., Lazar B., Mackelworth P., et al. 2012. Rare or just unknown? The occurrence of the giant devil ray (Mobula mobu- 
lar) in the Adriatic Sea. J. Appl. Ichthyol. 29: 1-6. https://doi.org/10.1111/jai.12034

Isajlovic I., Vrgoc N., Zorica B., et al. 2009. Age, growth and lengthweight relationship of Coelorinchus caelorhincus (Risso, 1810) in the Adriatic Sea. Acta Adriat. 50: 23-30.

Jereb P., Cannas R., Maiorano P., et al. 2016. The deepwater squid Octopoteuthis sicula Rüppell, 1844 (Cephalopoda: Octopoteuthidae) as the single species of the genus occurring in the Mediterranean Sea. Mar. Biol.: 163-192. https://doi.org/10.1007/s00227-016-2965-0

Joher S., Ballesteros E., Cebrian E., et al. 2012. Deep-water macroalgal-dominated coastal detritic assemblages on the continental shelf off Mallorca and Menorca (Balearic Islands, Western Mediterranean). Bot. Mar. 55: 485-497. https://doi.org/10.1515/bot-2012-0113

Joher S., Ballesteros E., Rodríguez-Prieto C. 2015. Contribution to the study of deep coastal detritic bottoms: the algal communities of the continental shelf off the Balearic Islands, Western Mediterranean. Mediterr. Mar. Sci. 16: 573-590. https://doi.org/10.12681/mms.1249

Joher S., Ballesteros E., Rodríguez-Prieto C. 2016. Macroalgaldominated coastal detritic communities from the Western Mediterranean and the Northeastern Atlantic. Mediterr. Mar. Sci. 17: 476-495. https://doi.org/10.12681/mms.1438

Johnson A.F., Valls M., Moranta J., et al. 2012. Effect of prey abundance and size on the distribution of demersal fishes. Can. J. Fish. Aquat. Sci. 69: 191-200. https://doi.org/10.1139/f2011-138

Kallianiotis A., Vidoris P., Sylaios G. 2004. Fish species assemblages and geographical sub-areas in the North Aegean Sea, Greece. Fish. Res. 68: 171-187. https://doi.org/10.1016/j.fishres.2003.12.007

Kasapides P., Peristeraki P., Tserpes G., et al. 2007. A new record of the Lessepsian invasive fish Etrumeus teres (Osteichthyes: Clupeidae) in the Mediterranean Sea (Aegean, Greece). Aquat. Invasions 2: 152-154. https://doi.org/10.3391/ai.2007.2.2.12

Katsanevakis S., Lefkaditou E., Galinou-Mitsoudi S., et al. 2008. Molluscan diversity and conservation: species of minor commercial interest in Hellenic Seas. Mediterr. Mar. Sci. 9: 77-11. https://doi.org/10.12681/mms.145

Keller S., Valls M., Hidalgo M., et al. 2014. Influence of environmental parameters on the life-history and population dynamics of cuttlefish Sepia officinalis in the western Mediterranean. Estuar. Coast. Shelf Sci. 145: 31-40. https://doi.org/10.1016/j.ecss.2014.04.016

Keller S., Bartolino V., Hidalgo M., et al. 2016. Large-scale spatiotemporal patterns of mediterranean cephalopod diversity. PLoS ONE 11: e0146469. https://doi.org/10.1371/journal.pone.0146469

Keller S., Hidalgo M., Álvarez-Berastegui D., et al. 2017. Demersal cephalopod communities in the Mediterranean: a large-scale analysis. Mar. Ecol. Prog. Ser. 584: 105-118. https://doi.org/10.3354/meps12342

Keller S., Quetglas A., Puerta P., et al. 2017. Environmentally driven synchronies of Mediterranean cephalopod populations. Prog. Oceanogr. 152: 1-14. https://doi.org/10.1016/j.pocean.2016.12.010

Kousteni V., Kontopoulou M., Megalofonou P. 2010. Sexual maturity and fecundity of Scyliorhinus canicula (Linnaeus, 1758) in the Aegean Sea. Mar. Biol. Res. 6: 390-398. https://doi.org/10.1080/17451000903233771

Kovačić M., Ordines F., Schliewen U.K. 2017. A new species of Buenia (Teleostei: Gobiidae) from the western Mediterranean Sea, with the description of this genus. Zootaxa. 4250: 447-460. https://doi.org/10.11646/zootaxa.4250.5.3

Krstulovic Sifner S., Lefkaditou E., Ungaro N., et al. 2005. Composition and distribution of the cephalopod fauna in the eastern Adriatic and eastern Ionian Sea. Israel J. Zool. 51: 315-330. https://doi.org/10.1560/4LT4-K01W-C9GF-7YK3

Krstulovic Sifner S., Vrgoc N., Dadic V., et al. 2009. Long-term changes in distribution and demographic composition of thornback ray, Raja clavata, in the northern and central Adriatic Sea. J. Appl. Ichthyol. 25: 40-46. https://doi.org/10.1111/j.1439-0426.2008.01204.x

Lauria V., Gristina M., Attrill M.J., et al. 2015. Predictive habitat suitability models to aid conservation of elasmobranch diversity in the central Mediterranean Sea. Sci. Rep. 5:13245. https://doi.org/10.1038/srep13245
Lauria V., Garofalo G., Gristina M., et al. 2016. Contrasting habitat selection amongst cephalopods in the Mediterranean Sea: When the environment makes the difference. Mar. Env. Res. 119: 252-266. https://doi.org/10.1016/j.marenvres. 2016.06.011

Lauria V., Garofalo G., Fiorentino F., et al. 2017. Species distribution models of two critically endangered deep-sea octocorals reveal fishing impacts on vulnerable marine ecosystems in central Mediterranean Sea. Sci. Rep. 7: 8049. https://doi.org/10.1038/s41598-017-08386-z

Le Bourg B., Bănaru D., Saraux C., et al. 2016. Trophic niche overlap of sprat and commercial small pelagic teleosts in the Gulf of Lions (NW Mediterranean Sea). J. Sea. Res. 103: 138-146. https://doi.org/10.1016/j.seares.2015.06.011

Lebrato M., Pitt K.A., Sweetman A, et al. 2012. Jelly-falls historic and recent observations: A review to drive future research directions. Hydrobiologia 698: 227-245. https://doi.org/10.1007/s10750-012-1046-8

Lebrato M., Molinero J.C., Cartes J.E., et al. 2013. Sinking JellyCarbon Unveils Potential Environmental Variability along a Continental Margin. PLoS ONE 8(12): e82070. https://doi.org/10.1371/journal.pone.0082070

Lefkaditou E. 2007. Review of Cephalopod fauna in Hellenic waters. In: Papaconstantinou C., Zenetos A., Vassilopoulou V., Tserpes G. (eds), State of Hellenic Fisheries. HCMR Publications, Athens, pp. 62-69.

Lefkaditou E., Peristeraki P., Bekas P., et al. 2003. Cephalopod distribution in the southern Aegean Sea. Mediterr. Mar. Sci. 4: 79-86. https://doi.org/10.12681/mms.243

Lefkaditou E., Politou C.-Y., Palialexis A., et al. 2008. Influences of environmental variability on the population structure and distribution patterns of the short-fin squid Illex coindetii (Cephalopoda: Ommastrephidae) in the Eastern Ionian Sea. Hydrobiologia 612: 71-90. https://doi.org/10.1007/978-1-4020-9141-4 6

Lefkaditou E., Tsigenopoulos C.S., Alidromiti C., et al. 2012. On the occurrence of Alloteuthis subulata in the Eastern Ionian Sea and its distinction from the sympatric Alloteuthis media. J. Biol. Res.Thessalon. 17: 169-175.

Levi D., Andreoli M.G., Bonanno A., et al. 2003. Embedding sea surface temperature anomalies in the stock recruitment relationship of red mullet (Mullus barbatus L. 1758) in the Strait of Sicily. Sci. Mar. 67: 259-268. https://doi.org/10.3989/scimar.2003.67s1259

Ligas A., Baino R., Barone M., et al. 2006. Analysis of trawl survey time series from the ligurian and the Tyrrhenian Seas. Biol. Mar. Mediterr. 13: 87-95.

Ligas A., De Ranieri S., Micheli D., et al. 2010. Analysis of the landings and trawl survey time series from the Tyrrhenian Sea (NW Mediterranean). Fish. Res. 105: 46-56. https://doi.org/10.1016/j.fishres.2010.03.003

Ligas A., Sartor P., Colloca F. 2011. Trends in population dynamics and fishery of Parapenaeus longirostris and Nephrops norvegicus in the Tyrrhenian Sea (NW Mediterranean): the relative importance of fishery and environmental variables. Mar. Ecol. 32: 25-35. https://doi.org/10.1111/j.1439-0485.2011.00440.x

Ligas A., Colloca F., Lundy M.G., et al. 2015. Modeling the growth of recruits of European hake (Merluccius merluccius) in the northwestern Mediterranean Sea with generalized additive models. Fish. Bull. 113: 69-81. https://doi.org/10.7755/FB.113.1.7

Lleonart J., Farrugio H. 2012. Pleuronectes platessa, a ghost fish in the Mediterranean Sea? Sci. Mar. 76: 141-147. https://doi.org/10.3989/scimar.03348.02B

Lloret J., Gil de Sola L., Souplet A., et al. 2002. Effects of largescale habitat variability on condition of demersal exploited fish in the north-western Mediterranean. ICES J. Mar. Sci. 59: 1215-1227. https://doi.org/10.1006/jmsc.2002.1294

Lloret J., Galzin R., Gil de Sola L., et al. 2005. Habitat related differences in lipid reserves of some exploited fish species in the north-western Mediterranean continental shelf. J. Fish. Biol. 67: 51-65. https://doi.org/10.1111/j.0022-1112.2005.00708.x

Louzao M. J. Navarro, A. Delgado-Huertas, L., et al. 2017. Surface oceanographic fronts influencing deep-sea biological activity: Using fish stable isotopes as ecological tracers Deep Sea Research Part II: Topical Studies in Oceanography, 140: 117-126. 
https://doi.org/10.1016/j.dsr2.2016.10.012

Mahe K., Ider D., Massaro A., et al. 2019. Directional bilateral asymmetry in otolith morphology may affect fish stock discrimination based on otolith shape analysis. ICES J. Mar. Sci. 76: $232-243$.

https://doi.org/10.1093/icesjms/fsy163

Maiorano P., D’Onghia G., Capezzuto F., et al. 2002. Life-history traits of Plesionika martia (Decapoda: Caridea) from the Eastern-Central Mediterranean Sea. Mar. Biol. 141: 527-539. https://doi.org/10.1007/s00227-002-0851-4

Maiorano L., Bartolino V., Colloca F., et al. 2009. Systematic conservation planning in the Mediterranean: a flexible tool for the identification of no-take marine protected areas. ICES J. Mar. Sci. 66: 137-146. https://doi.org/10.1093/icesjms/fsn 148

Maiorano P., Sion L., Carlucci R., et al. 2010. The demersal faunal assemblage of the North-Western Ionian Sea (Central Mediterranean): current knowledge and perspectives. Chemistry \& Ecology. Vol. 26 Suppl 1: 219-240. https://doi.org/10.1080/02757541003693987

Maiorano P., Capezzuto F., Sion L., et al. 2013. Spatio-temporal changes of Munida rutllanti Zariquiey-Alvarez, 1952 (Decapoda: Galatheidae) in the north-western Ionian Sea (Central Mediterranean). Mediterr. Mar. Sci. 14: 42-48. https://doi.org/10.12681/mms.619

Manfredi C., Ciavaglia E., Isajlovic I., et al. 2010. Temporal and spatial distribution of some elasmobranchs in the northern and central Adriatic Sea. Biol. Mar. Mediterr. 17: 254-255.

Mannini A., Reale B., Colloca F., et al. 2008. Applicazione della routine R-Sufi ai dati raccolti durante le campagne MEDITS 1995-2006 nella sub area geografica FAO 9. Biol. Mar. Mediterr. 15: 426-427.

Marano C. A., Manfrin Piccinetti G., Pasolini P., et al. 2002. Annotated checklist of the skates (Chondrichthyes, Rajidae) in the Adriatic Sea. Biol. Mar. Mediterr. 10: 856-862.

Marano C. A., Martino M., Marzano M. C., et al. 2006. Taglia di prima maturità di Illex coindetii (Verany, 1839) nell'Adriatico meridionale. Biol. Mar. Mediterr. 13: 881-883

Maravelias C. D., Tserpes G., Pantazi M., et al. 2012. Habitat Selection and Temporal Abundance Fluctuations of Demersal Cartilaginous Species in the Aegean Sea (Eastern Mediterranean). PLoS ONE 7: e35474. https://doi.org/10.1371/journal pone.0035474

Marino F., Busalacchi B., Bottari T., et al. 2016. Occurrence and prevalence of Philometra filiformis (Stossich, 1896) on Pagellus erythrinus (Linnaeus, 1758) in the Southern Tyrrhenian Sea. J. Appl. Ichthyol. 32: 687-692. https://doi.org/10.1111/jai.13069

Marongiu M.F., Bellodi A., Cau A., et al. 2013. Reproductive biology of the blackmouth catshark, Galeus melastomus Rafinesque, 1810, in Sardinian seas (central western Mediterranean). Biol. Mar. Mediter. 20: 190-191.

Marongiu M.F., Porcu C., Bellodi A., et al. 2015 Oviducal gland microstructure of Raja miraletus and Dipturus oxyrinchus (Elasmobranchii, Rajdae). J. Morphol. 276: 1392-1403. https://doi.org/10.1002/imor.20426

Marongiu M.F., Porcu C., Bellodi A., et al. 2017. Temporal dynamics of demersal chondrichthyan species in the central western Mediterranean Sea: The case study in Sardinia Island. Fish. Res. 193: 81-94.

https://doi.org/10.1016/j.fishres.2017.04.001

Marra A., Mona S., Sà R. M., et al. 2015. Population genetic history of Aristeus antennatus (Crustacea: Decapoda) in the Western and Central Mediterranean Sea. PLoS ONE 10: e0117272. https://doi.org/10.1371/journal.pone.0117272

Masnadi F., Viva C., Ligas A. 2017. Effetti di variabili ambientali ed antropiche sulle comunità ittiche di acque profonde nel Mar Ligure e Mar Tirreno settentrionale. Biol. Mar. Mediterr. 24: 190-191.

Massaro A., Ligas A., Carbonara P. 2014. Accrescimento della boga Boops boops (Linneo, 1758), nel Mar Ligure e nel Mar Tirreno centro-settentrionale. Biol. Mar. Mediterr. 21: 285-286.

Massaro A., Fortuna C., Ligas A. 2016. Accrescimento di Lophius budegassa Spinola, 1807 nel Mar Ligure e Tirreno settentrionale. Biol. Mar. Mediterr. 23: 264-265.

Massaro A., Sartini M., Sbrana M. 2017. Reproductive periods of demersal species in the Ligurian and northern-central Tyrrhenian Seas. Biol. Mar. Mediterr. 24: 192-193.

Massi D., Titone A., Mancuso M., et al. 2015. Neptunea contraria and Buccinum undatum (Gastropoda, Buccinidae) thanato- coenosis in the Strait of Sicily. Biol. Mar. Mediterr. 22: 99-100.

Massi D., Titone A., Colloca F., et al. 2016. Are Leptometra phalangium (Echinodermata, Antedonidae) beds nursery habitats for hake in the Strait of Sicily? Biol. Mar. Mediterr. 23: 266-268.

Massutí E., Moranta J. 2003. Demersal assemblages and depth distribution of elasmobranchs from the continental shelf and slope trawling grounds off the Balearic Islands (western Mediterranean). ICES J. Mar. Sci. 60: 753-766. https://doi.org/10.1016/S1054-3139(03)00089-4

Massutí E., Reñones O. 2005. Demersal resource assemblages in the trawl fishing grounds off the Balearic Islands (western Mediterranean). Sci. Mar. 69: 167-181. https://doi.org/10.3989/scimar.2005.69n1167

Massutí E., Reina J.A., Lloris D., et al. 2002. First record of Solea (Microchirus) boscanion (Osteichthyes: Soleidae) in the Mediterranean Sea, with data on other sympatric soleid species. J. Mar. Biol. Assoc. U.K. 82: 907-911. https://doi.org/10.1017/S002531540200633

Mastrototaro F., Chimienti G., Capezzuto F., et al. 2014. First record of Protoptilum carpenteri (Cnidaria: Octocorallia: Pennatulacea) in the Mediterranean Sea. Ital. J. Zool. 2014:1-8. https://doi.org/10.1080/11250003.2014.982218

Mazzoldi C., Finotto L., Gristina M., et al. 2015. Contrasting life history and reproductive traits in two populations of Scyliorhinus canicula. Mar. Biol. 162: 1175-1186. https://doi.org/10.1007/s00227-015-2659-z

Melis R., Vacca L., Cuccu D., et al. 2017. Genetic population structure and phylogeny of the common octopus Octopus vulgaris Cuvier, 1797 in the western Mediterranean Sea through nuclear and mitochondrial markers. Hydrobiologia 807: 277-296. https://doi.org/10.1007/s10750-017-3399-5

Mérigot B., Bertrand J., Gaertner J.C., et al. 2007. The multicomponent structuration of the species diversity of groundfish assemblages of the east coast of Corsica (Mediterranean Sea): Variation according to the bathymetric strata. Fish. Res. 88: 120-132.

https://doi.org/10.1016/j.fishres.2007.08.003

Mérigot B., Bertrand J., Mazouni N., et al. 2007. A multi-component analysis of species diversity of groundfish assemblages on the continental shelf of the Gulf of Lions (north-western Mediterranean Sea). Est. Coast. Shelf Sci. 73: 123-136. https://doi.org/10.1016/j.ecss.2006.12.017

Mezzasalma V., Zagra M., Di Stefano L., et al. 2008. Evidence of lipofuscin accumulation in the deep-water red shrimp Aristaeomorpha foliacea (Risso, 1827). Mediterr. Mar. Sci. 9: 21-33. https://doi.org/10.12681/mms.130

Milisenda G., Garofalo G., Fezzani S., et al. 2017. Biomass HotSpot distribution model and spatial interaction of two exploited species of horse mackerel in the south-central Mediterranean Sea. Hydrobiologia 821: 135-150. https://doi.org/10.1007/s10750-017-3336-7

Moranta J., Massutí E., Palmer M., et al. 2007. Geographic and bathymetric trends in abundance, biomass and body size of four grenadier fishes along the Iberian coast in the western Mediterranean. Prog. Oceanogr. 72: 63-83. https://doi.org/10.1016/j.pocean.2006.09.003

Morat F., Letourneur Y., Dierking J., et al. 2014. The great melting pot. Common sole population connectivity assessed by otolith and water. PLoS ONE 9: e86585. https://doi.org/10.1371/journal.pone.0086585

Morfin M., Bez N., Fromentin J-M. 2016. Habitats of ten demersal species in the Gulf of Lions and potential implications for spatial management. Mar. Ecol. Prog. Ser. 547: 219-232. https://doi.org/10.3354/meps11603

Morfin M., Fromentin J.M., Jadaud A., et al. 2012. Spatio-Temporal patterns of key exploited marine species in the North-western Mediterranean Sea. PLoS ONE 7: e37907. https://doi.org/10.1371/journal.pone.0037907

Mulas A., Bellodi A., Cannas R., et al. 2015. Diet and feeding behaviour of longnosed skate Dipturus oxyrinchus. J. Fish Biol. 86: 121-138. https://doi.org/10.1111/jfb.12551

Mulas A., Bellodi A., Cau Al., et al. 2011. Trophic interactions among Chondrichthyans in the central-western Mediterranean Sea. Biol. Mar. Mediterr. 18: 81-84.

Mulazzani L., Manrique R., Trevisan G., et al. 2015. The relationship among catch, fishing effort, and measures of fish stock abundance: implications in the Adriatic Sea. Can. J. Fish. Aquat. Sci. 72: 410-421.

https://doi.org/10.1139/cjfas-2014-0337 
Murenu M., Cau A., Colloca F., Sartor P., et al. 2010. Mapping the potential locations of European hake (Merluccius merluccius) nurseries in the Italian waters. In: Nishida T., and Caton A.E. (Eds), GIS/Spatial Analyses in Fishery and Aquatic Sciences (Vol. 4). International Fishery GIS Society, Saitama, Japan. pp. 51-68.

Navarro J., Coll M., Cardador L., et al. 2015. The relative roles of the environment, human activities and spatial factors in the spatial distribution of marine biodiversity in the Western Mediterranean Sea. Prog. Oceanogr. 131: 126-137. https://doi.org/10.1016/j.pocean.2014.12.004

Nobile E., Lanteri L., Mannini A., et al. 2008. Accrescimento di due specie di Trachurus in Mar Ligure. Biol. Mar. Mediterr. 15: 342-343.

Ordines F., Massutí E. 2009. Relationships between macro-epibenthic communities and fish on the shelf grounds of the western Mediterranean. Aquat. Conserv. 19: 370-383. https://doi.org/10.1002/aqc.969

Ordines F., Quetglas A., Massutí E., et al. 2009. Habitat preferences and life history of the red scorpion fish, Scorpaena notata, in the Mediterranean. Estuar. Coast. Shelf Sci. 85: 537-546. https://doi.org/10.1016/i.ecss.2009.09.020

Ordines F., Massutí E., Moranta J., et al. 2011. Balearic Islands vs. Algeria: two nearby western Mediterranean elasmobranchs populations with different oceanographic scenarios and fishing histories. Sci. Mar. 75: 707-717. https://doi.org/10.3989/scimar.2011.75n4707

Ordines F., Valls M., Gouraguine A. 2012. Biology, feeding and habitat preferences of cadenat's rockfish, Scorpaena loppei (Actinopterygii: Scorpaeniformes: Scorpaenidae), in the Balearic Islands (Western Mediterranean). Acta Ichthyol. Piscat. 42: 21-30. https://doi.org/10.3750/AIP2011.42.1.03

Ordines F., Farriols M.T., Lleonart J., et al. 2014. Biology and population dynamics of by-catch fish species of the bottom trawl fishery in the Western Mediterranean. Mediterr. Mar. Sci. 15: 613-625. https://doi.org/10.12681/mms.812

Ordines F., Bauzá M., Sbert M., et al. 2015. Red algae beds increase the condition of nekto-benthic fish. J. Sea Res. 95: 115-123. https://doi.org/10.1016/j.seares.2014.08.002

Orsi Relini L., Mannini A., Fiorentino F., et al. 2006. Biology and fisheries of Eledone cirrhosa in the Ligurian Sea. Fish. Res. 78: 72-88. https://doi.org/10.1016/j.fishres.2005.12.008

Orsi Relini L., Mannini A., Relini G. 2013. Updating knowledge on growth, population dynamics, and ecology of the blue and red shrimp, Aristeus antennatus (Risso, 1816), on the basis of the study of its instars. Mar. Ecol. 34: 90-102. https://doi.org/10.1111/j.1439-0485.2012.00528.x

Osio G.C., Orio A., Millar C.P. 2015. Assessing the vulnerability of Mediterranean demersal stocks and predicting exploitation status of un-assessed stocks. Fish. Res. 171: 110-121. https://doi.org/10.1016/j.fishres.2015.02.005

Palero F., Guerao G., Abelló P. 2008. Morphology of the final stage phyllosoma larva of Scyllarus pygmaeus (Crustacea: Decapoda: Scyllaridae), identified by DNA analysis. J. Plankton Res. 30(4): 483-488 https://doi.org/10.1093/plankt/fbn012

Palero F. Guerao G., Clark P.F., Abelló P. 2011. Scyllarus arctus (Crustacea: Decapoda: Scyllaridae) final stage phyllosoma identified by DNA analysis, with morphological description. J. Mar. Biol. Assoc. U.K. 91(2): 485-492. https://doi.org/10.1017/s0025315410000287

Palmas F., Addis P., Cabiddu S., et al. 2015. Distribution of spawning and nursery grounds for deep-water red shrimps in the central western Mediterranean Sea. Mediterr. Mar. Sci. 16: $117-127$ https://doi.org/10.12681/mms.859

Paradinas I., Conesa D., Pennino M.G., et al. 2015. Bayesian spatiotemporal approach to identifying fish nurseries by validating persistence areas. Mar. Ecol. Prog. Ser. 528: 245-255. https://doi.org/10.3354/meps11281

Pascual M., Palero F., García-Merchán V.H., et al. 2016. Temporal and spatial genetic differentiation in the crab Liocarcinus depurator across the Atlantic-Mediterranean transition. Sci. Rep. 6: 29892

https://doi.org/10.1038/srep29892

Pennino M.G., D. Conesa, A. López-Quílez, F. et al. 2016. Fisherydependent and -independent data lead to consistent estimations of essential habitats. ICES J. Mar. Sci. 73: 2302-2310. https://doi.org/10.1093/icesims/fsw062

Perdichizzi A., Pirrera L., Giordano D., et al. 2007. Distribuzione e note biologiche di Galeus melastomus (Chondrichthyes, Scyliorhinidae) nel Mar Tirreno meridionale (Mediterraneo centrale). Biol. Mar. Mediterr. 14: 356-357.

Perdichizzi A., Pirrera L., Profeta A., et al. 2008. Distribuzione spaziale di reclute di Galeus melastomus (Choindrichthyes, Scyliorhinidae) nel Mar Tirreno meridionale (Mediterraneo centrale). Biol. Mar. Mediterr. 15: 344-345.

Perdichizzi A., Pirrera L., Giordano D., et al. 2011. Distribution patterns and population structure of Illex coindetii (Cephalopoda: Ommastrephidae) in the Southern Tyrrhenian Sea: historical series of 14 years trawl survey. Fish. Res. 109: 342-350. https://doi.org/10.1016/j.fishres.2011.03.001

Perdichizzi A., Pirrera L., Micale V., et al. 2012. A histological study of ovarian development in the Giant red shrimp Aristaeomorpha foliacea (Crustacea: Decapoda: Aristeidae) from the Southern Tyrrhenian Sea (Western Mediterranean). Sci. World J. 2012: 289608 https://doi.org/10.1100/2012/289608

Perdichizzi A., Profeta A., Fiorentino F., et al. 2012. Use of GIS for representation of nursery areas of deep shrimp Aristaeomorpha foliacea and Aristeus antennatus. Biol. Mar. Mediterr. 19: 112-113.

Peristeraki P., Megalophonou P. 2007. Sharks and Rays. In: Papaconstantinou C., Zenetos A., Vassilopoulou V., Tserpes G. (eds), State of Hellenic Fisheries. HCMR Publications, Athens, pp. 433-439.

Peristeraki P., Lazarakis G., Skarvelis C., et al. 2006. Additional records on the occurrence of alien fish species in the eastern Mediterranean Sea. Mediterr. Mar. Sci. 7: 61-66. https://doi.org/10.12681/mms.170

Peristeraki P., Tserpes G., Lampadariou N., et al. 2017. Comparing demersal megafaunal species diversity along the depth gradient within the South Aegean and Cretan Seas (Eastern Mediterranean). PLoS ONE 12: e0184241. https://doi.org/10.1371/journal.pone.0184241

Pham C., Ramirez-Llodra E., Amaro T., et al. 2014. Marine litter distribution and abundance in European Seas, from the shelf to deep basins. PLoS ONE 9: e95839. https://doi.org/10.1371/journal.pone.0095839

Pinto C., Mannini A., Relini G. 2010. Remarks on Galeus melastomus in the northern Ligurian Sea. Biol. Mar. Mediterr. 17: 224-227.

Pirrera L., Bottari T., Busalacchi B , et al. 2009. Distribution and population structure of the fish Helicolenus dactylopterus dactylopterus (Delaroche, 1809) in the Central Mediterranean (Southern Tyrrhenian Sea). Mar. Ecol. 30: 161-174. https://doi.org/10.1111/j.1439-0485.2009.00327.x

Politou C. Y. 2007. Current state of demersal fisheries resources. In: Papaconstantinou C., Zenetos A., Vassilopoulou V., Tserpes G. (eds), State of Hellenic Fisheries. HCMR Publications, Athens, pp. 183 .

Politou C.-Y., Peristeraki P., Kallianiotis A. 2007. Fisheries independed assessment methods: Demersal surveys. In: Papaconstantinou C., Zenetos A., Vassilopoulou V., Tserpes G. (eds), State of Hellenic Fisheries. HCMR Publications, Athens, pp. 360-368.

Politou C.-Y., Tserpes G., Dokos J. 2008. Identification of deepwater pink shrimp abundance distribution patterns and nursery grounds in the eastern Mediterranean by means of generalized additive modelling. Hydrobiologia 612: 99-107. https://doi.org/10.1007/s10750-008-9488-8

Porcu C., Mulas A., Cabiddu S., et al. 2010. Reproductive biology of the blonde ray Raja brachyura (Chondrichthyes: Rajidae) in Sardinian Seas. Biol. Mar. Mediterr. 17: 256-257.

Porcu C., Marongiu M.F., Follesa M.C., et al. 2014. Reproductive aspects of the velvet belly Etmopterus spinax (Chondrichthyes: Etmopteridae), from the central western Mediterranean Sea. Notes on gametogenesis and oviducal gland microstructure Mediterranean. Mar. Sci. 15: 313-326. https://doi.org/10.12681/mms.559

Porcu C., Bellodi A., Cannas R. 2015. Life-history traits of the commercial blonde ray, Raja brachyura from the central-western Mediterranean Sea. Mediterr. Mar. Sci. 16: 90-102. https://doi.org/10.12681/mms.898

Porcu C., Marongiu M.F., Bellodi A., et al. 2017. Morphological descriptions of the eggcases of skates (Rajidae) from the central Western Mediterranean, with notes on their distribution. Helgo- 
land Mar. Res. 71: 10. https://doi.org/10.1186/s10152-017-0490-2

Profeta A., Busalacchi B., Perdichizzi A., et al. 2008. Distribuzione e biologia del cefalopode Illex coindetii (Verany, 1839) nel Mar Tirreno Meridionale. Biol. Mar Mediterr. 15: 348-349.

Puerta P., Hidalgo M., González M., et al. 2014. Role of hydroclimatic and demographic processes on the spatio-temporal distribution of cephalopods in the Western Mediterranean. Mar. Ecol. Prog. Ser. 514: 105-118. https://doi.org/10.3354/meps10972

Puerta P., Hunsicker M.E., Quetglas A., et al. 2015. Spatially explicit modeling reveals cephalopod distributions match contrasting trophic pathways in the Western Mediterranean Sea. PLOS ONE. 10: e 013343 https://doi.org/10.1371/journal.pone.0133439

Puerta P., Hunsicker M.E., Reglero P., et al. 2016. Communityenvironment interactions explain octopus-catshark spatial overlap. ICES J. Mar. Sci. 73: 1901-1911. https://doi.org/10.1093/icesjms/fsw053

Puerta P., Quetglas A., Hidalgo M. 2016. Seasonal variability of cephalopod populations: a spatio-temporal approach in the Western Mediterranean Sea. Fish.Oceanogr. 25: 373-389. https://doi.org/10.1111/fog.12159

Quattrocchi F., Garofalo G., Di Stefano G., et al. 2014. Variabilità morfologica della triglia di fango (Mullus barbatus, Linnaeus, 1758) lungo la costa nord-occidentale della Sicilia. Biol. Mar. Mediterr. 21: 293-295.

Quetglas A., González M., Carbonell A., et al. 2001. Biology of the deep-sea octopus Bathypolypus sponsalis (Cephalopoda: Octopodidae) from the western Mediterranean. Mar. Biol. 138: 785-792. https://doi.org/10.1007/s002270000495

Quetglas A., González M., Franco I. 2005. Biology of the deep-sea cephalopod Octopus salutii from the western Mediterranean Sea. Mar. Biol. 146: 1131-1138. https://doi.org/10.1007/s00227-004-1522-4

Quetglas A., Ordines F., González M., Franco I. 2009. Life history of the bathyal octopus Pteroctopus tetracirrhus (Mollusca, Cephalopoda) in the Mediterranean Sea. Deep-Sea Res Part I. 56: $1379-1390$ https://doi.org/10.1016/j.dsr.2009.02.007

Quetglas A., de Mesa A., Ordines F., et al. 2010. Life history of the deep-sea cephalopod family Histioteuthidae in the western Mediterranean. Deep-Sea Res Part I. 57: 999-1008. https://doi.org/10.1016/j.dsr.2010.04.008

Quetglas A., Guijarro B., Ordines F., et al. 2012. Stock boundaries for fisheries assessment and management in the Mediterranean: the Balearic Islands as a case study. Sci. Mar. 76: 17-28. https://doi.org/10.3989/scimar.2012.76n1017

Quetglas A., Ordines F., González M., et al. 2013. Uncommon pelagic and deep-sea cephalopods in the Mediterranean: new data and literature review. Mediterr. Mar. Sci. 14: 69-85. https://doi.org/10.12681/mms.320

Quetglas A., Rueda L., Álvarez-Berasategui D., et al. 2016. Contrasting responses to harvesting and environmental drivers of fast and slow life history species. PLoS ONE 11: e0148770. https://doi.org/10.1371/journal.pone.0148770

Ragonese S., Fiorentino F., Rinelli P., et al. 2002. A procedure to evaluate the effect of lag-time in studying length structure and growth rate of young fish: the case of Phycis blennoides Brunnich, 1768 (Osteichthyes: Gadiformes) in the Central Mediterranean. Sci. Mar. 66S2: 253-260. https://doi.org/10.3989/scimar.2002.66s2253

Ragonese S., Fiorentino F., Rinelli P., et al. 2002. Towards the joint analysis of different trawl data sets in the assessment of the Mediterranean resources: a procedure to evaluate the effect of lag time in the sample structures of Phycis blennoides, Brunnich, 1768 (Pisces; Gadiformes). Sci. Mar. 66: 253-260. https://doi.org/10.3989/scimar.2002.66s2253

Ragonese S., Morizzo G., De Santi A., et al. 2005. Rapid-response indicators of changes in resource state based on Mediterranean bottom-trawl surveys. ICES J. Mar. Sci. 62: 511-515. https://doi.org/10.1016/j.icesjms.2004.11.008

Ragonese S., Nardone G., Ottonello D., et al. 2009. Distribution and biology of the Blackmouth catshark Galeus melastomus in the Strait of Sicily (Central Mediterranean Sea). Mediterr. Mar. Sci. 10: $55-72$. https://doi.org/10.12681/mms.122

Ragonese S., Vitale S., Dimech M., De Santi A. 2011. Growth discontinuity in males of the deep-water giant red shrimp Aris- taeomorpha foliacea in the Mediterranean Sea. Mar. Ecol. 33: 386-392.

https://doi.org/10.1111/j.1439-0485.2011.00492.x

Ragonese S., Vitale S., Dimech M., et al. 2013. Abundances of Demersal Sharks and Chimaera from 1994-2009 Scientific Surveys in the Central Mediterranean Sea. PLoS ONE 8: e74865. https://doi.org/10.1371/journal.pone.0074865

Ramírez-Amaro S., Ordines F., Terrasa B., et al. 2015. Demersal chondrichthyans along the Western Mediterranean: assemblages and biological parameters of their main species. Mar. Freshw. Res. 67: 636-652. https://doi.org/10.1071/MF15093

Ramírez-Amaro S., Ordines F., Puerto M.A., et al. 2017. New morphological and molecular evidence confirm the presence of the Norwegian skate Dipturus nidarosiensis (Storm, 1881) in the Mediterranean Sea and extend its distribution to the western basin. Mediterr. Mar. Sci. 18: 253-261. https://doi.org/10.12681/mms.1950

Ramón M., Lleonart J., Massutí E. 2010. Royal cucumber (Stichopus regalis) in the northwestern Mediterranean: Distribution pattern and fishery. Fish. Res. 105: 21-27. https://doi.org/10.1016/j.fishres.2010.02.006

Relini G. 2015. Biodiversità ittica delle campagne Medits (Fish biodiversity in Medits surveys). Biol. Mar. Mediterr. 22: 176-177.

Relini G., Franco A. 2012. La ricchezza in specie dei mari italiani. Biol. Mar. Mediterr. 19: 263-264.

Relini G., Mannini A., De Ranieri S., et al. 2010. Chondrichthyes caught during the MEDITS surveys in the Italian waters. Biol. Mar. Mediterr. 17: 186-204.

Relini G., Lanteri L., Franco A. 2011. Gli Osteitti dei mari italiani: biodiversità, protezione e sfruttamento. Biol. Mar. Mediterr. 18: 44-47.

Relini G., Vallarino G. 2016. La ricchezza in specie dei crostacei decapodi delle campagne MEDITS (Species richness of crustacea decapoda of MEDITS survey). Biol. Mar. Mediterr. 23: 277-278

Relini Orsi L., Papaconstantinou C., Jukic-Peladic S., et al. 2002. Distribution of the Mediterranean hake populations (Merluccius merluccius smiridus Rafinesque, 1810) (Ostheichthyes: Gadiformes) based on six years monitoring by trawl-surveys: some implications for management. Sci. Mar. 66(Suppl. 2): 21-38. https://doi.org/10.3989/scimar.2002.66s221

Relini Orsi L., Mannini A., Lanteri L., et al. 2009. First record of an egg mass of Loligo forbesi (Cephalopoda: Loliginidae) in the Ligurian Sea, with notes about egg laying patterns in southern populations. Boll. Malacol. 45: 27-33.

Rey J., Gil de Sola L., Massutí E. 2005. Distribution and biology of the blackmouth catshark Galeus melastomus in the Alboran Sea. J. Northwest Atl. Fish. Sci. 35: 1-9. https://doi.org/10.2960/J.v35.m484

Rey J., Seret B., Lloris D., et al. 2006. A new redescription of Galeus atlanticus (Vaillant, 1888) (Chondrichthyes: Scyliorhinidae) based on field marks. Cybium 30(4): 7-14.

Rey J., Coelho R., Lloris D., et al. 2010. Distribution pattern of Galeus atlanticus in the Alborán Sea (south western Mediterranean) and some sexual character comparison with Galeus melastomus. Mar. Biol. Res. 6(4): 364-372. https://doi.org/10.1080/17451000903042487

Ribas D., M. Muñoz, M. Casadevall, et al. 2006. How does the northern Mediterranean population of Helicolenus dactylopterus dactylopterus resist fishing pressure? Fish. Res. 79: 285-293. https://doi.org/10.1016/j.fishres.2006.03.022

Rinelli P., Bottari T., Florio G., et al. 2005. Observations on distribution and biology of Galeus melastomus (Chondrichthyes, Scyliorhinidae) in the Southern Tyrrhenian Sea (Central Mediterranean). Cybium 29: 41-46.

Rinelli P., Bianchini M.L., Casciaro L., et al. 2013. Occurrence and abundance of the deep-water red shrimps Aristeus antennatus (Risso, 1816) and Aristaeomorpha foliacea (Risso, 1827) in the Mediterranean Sea. Cah. Biol. Mar. 54: 335-347.

Rochet M.J., Trenkel V., Bellail R., et al. 2005. Combining indicator trends to assess ongoing changes in exploited fish communities: diagnostic of communities off the coasts of France. ICES J. Mar. Sci. 62: 1647-1664. https://doi.org/10.1016/j.icesjms.2005.06.009

Rochet M.J., Trenkel V., Carpentier A., et al. 2010. Do changes in environmental and fishing pressures impact marine communities? An empirical assessment. J. Appl. Ecol. 47: 741-750. https://doi.org/10.1111/j.1365-2664.2010.01841.x 
Romeo T., Castriota L., Consoli P., et al. 2009. Bathymetric and longitudinal distribution analysis of the rockfish Helicolenus dactylopterus (Delaroche, 1809) in the Southern Tyrrhenian Sea (central Mediterranean). Medit. Mar. Sci. 10: 73-82. https://doi.org/10.12681/mms.123

Rueda L., Massutí E., Álvarez-Berastegui D., et al. 2015. Effect of intra-specific competition, surface chlorophyll and fishing on spatial variation of gadoid's body condition. Ecosphere 6: 1-17. https://doi.org/10.1890/ES15-00087.1

Rufino M.M., Maynou F., Abelló P., et al. 2005. The effect of methodological options on geostatistical modelling of animal distribution: A case study with Liocarcinus depurator (Crustacea: Brachyura) trawl survey data. Fish.Res. 76: 252-265. https://doi.org/10.1016/j.fishres.2005.06.014

Rufino M.M., Abelló P., Yule A.B., et al. 2005. Geographic, bathymetric and inter-annual variability in the distribution of Liocarcinus depurator (Brachyura: Portunidae) along the Mediterranean coast of the Iberian Peninsula. Sci. Mar. 69(4): 503-518. https://doi.org/10.3989/scimar.2005.69n4503

Rufino M.M., Maynou F., Abelló P., et al. 2006. Geostatistical analysis of densities of Liocarcinus depurator (Brachyura: Portunidae) on the western Mediterranean from 1994 to 2003. Mar. Biol. 149. 855-864. https://doi.org/10.1007/s00227-006-0253-0

Rufino M.M., Abelló P., Yule A.B. 2006. Geographic and gender shape differences in the carapace of Liocarcinus depurator (Brachyura: Portunidae) using geometric morphometrics and the influence of a digitising method. J. Zool. 269: 458-465. https://doi.org/10.1111/j.1469-7998.2006.00086.x

Russo T., Parisi A., Garofalo G., et al. 2014. SMART: A Spatially Explicit Bio-Economic Model for Assessing and Managing Demersal Fisheries, with an Application to Italian Trawlers in the Strait of Sicily. PLoS ONE 9: e86222. https://doi.org/10.1371/journal.pone.0086222

Russo T, Bitetto I, Carbonara P, et al. 2017. A holistic approach to fishery management: evidence and insights from a Central Mediterranean case study (Western Ionian Sea). Front. Mar. Sci. 4: 193. https://doi.org/10.3389/fmars.2017.00193

Sabatini A., Locci I., Deiana A., et al. 2013. Temporal trends in biodiversity of the middle-slope assemblages in Sardinian seas (Central-Western Mediterranean). J. Mar. Biol. Assoc. U.K. 93: 1739-1752. https://doi.org/10.1017/S0025315413000258

Sartor P., Sbrana M., Ungaro N., et al. 2002. Distribution and abundance of Citharus linguatula, Lepidorhombus boscii (Risso, 1810 ) and Solea vulgaris, (Osteichthyes, Pleuronectiformes) in the Mediterranean Sea. Sci. Mar. 66(Suppl. 2): 83-102. https://doi.org/10.3989/scimar.2002.66s283

Sartor P., Colloca F., Ligas A., et al. 2013. Ruolo delle aree di nursery per i giovanili di nasello, Merluccius merluccius (L., 1758), nella GSA 9. Biol. Mar. Mediterr. 20: 204-205

Sartor P., Mannini A., Carlucci R., et al. (eds). 2017. Sintesi delle conoscenze di biologia, ecologia e pesca delle specie ittiche dei mari italiani / Synthesis of the knowledge on biology, ecology and fishery of the halieutic resources of the Italian seas. Biol. Mar. Mediterr. 24 (Suppl. 1): 607 pp.

Sbrana M., Colloca F., Ligas A., et al. 2015. Abundance of blackmouth catshark, Galeus melastomus, in the FAO GFCM GSA 9 (Ligurian and northern central Tyrrhenian Sea) and identification of nursery grounds Biol. Mar. Mediterr. 22: 182-183.

Sbrana M., Rossetti I., De Ranieri S., et al. 2014. Prime osservazioni sulla fauna ittica profonda del Mar Tirreno settentrionale. Biol. Mar. Mediterr. 21: 307-309.

Sbrana M., Sartor P., Ghidi M., et al. 2009. Aspetti di biologia di Nephrops norvegicus (L., 1758) (Crustacea: Decapoda) nel mar Tirreno settentrionale. Biol. Mar. Mediterr. 16: 366-367.

Serena F., Barone M., Mancusi C. 2010. Mediterranean Cartilaginous Fishes: 25 Years of Italian Research. Biol. Mar. Mediterr. 17: 232-235.

Serena F., Barone M., Mancusi C., et al. 2005. Reproductive biology, growth and feeding habits of Raja asterias Delaroche, 1809, from the North Tyrrhenian and South Ligurian Sea (Italy), with some notes on trends in landings. International Council for the Exploration of the Sea. Theme session on Elasmobranch Fisheries Science, CM 2005/n. 12, Fisheries Science, 18 pp.

Serena F., Papaconstantinou C., Relini G., et al. 2009. 12. Distribution and abundance of spiny dogfish in the Mediterranean Sea based on the Mediterranean International Trawl Survey Program. In Gallucci V., McFarlane G., Bargmann G. (eds), Bi- ology and Management of Dogfish Sharks, American Fisheries Society, Bethesda, pp. 139-149.

Simão D.S., Zas E., Carbonell A., et al. 2015. Pasiphaeid shrimps in the western Mediterranean: geographical variability in distribution and population patterns. Sci. Mar. 79(2): 199-209. https://doi.org/10.3989/scimar.04147.07A

Simão D.S., Pérez Gil J.L., Abelló P. 2017. Sexual dimorphism and associated population characteristics in the benthopelagic shrimp Pasiphaea sivado (Crustacea: Caridea: Pasiphaeidae). Sci. Mar. 81: 57-66. https://doi.org/10.3989/scimar.04378.20A

Sion L., D’Onghia G., Tursi A., et al. 2003. Annotated check list of the skates (Chondrichthyes, Rajidae) in the North-Western Ionian Sea. Biol. Mar. Mediterr. 10: 935-940.

Sion L., Maiorano P., Carlucci R., et al. 2012. Review of the literature on age and growth of grenadiers in the Mediterranean and new data on age of Trachyrincus scabrus (Macrouridae) in the Ionian Sea. Journal of Ichthyology, vol. 52: 740-749. https://doi.org/10.1134/S0032945212100116

Sobrino I., Silva C., Sbrana M., et al. 2005. A review of the biology and fisheries of the deep water rose shrimp, Parapenaeus longirostris, in European Atlantic and Mediterranean waters (Decapoda, Dendrobranchiata, Penaeidae). Crustaceana 78: 1153-1184. https://doi.org/10.1163/156854005775903564

Spedicato M.T. 2016. Study on the evaluation of specific management scenarios for the preparation of multiannual management plans in the Mediterranean and the Black Sea. Final Report, 640 pp.

Spedicato M.T., Baino R., Carbonara P., et al. 2005. Un metodo per standardizzare "a posteriori" le stime di abbondanza dei trawlsurvey sulla base dei tempi operativi di cala. Biol. Mar. Med. 12: $589-593$

Spedicato M.T., Carbonara P., Rinelli P., et al. 2006. Biological reference points based on spawning stock biomass levels: the case of red mullet (Mullus barbatus L., 1758). Biol. Mar. Mediterr. 13: $112-123$

Spedicato M.T., Greco S., Sophronidis K., et al. 2002. Geographical distribution, abundance and some population characteristics of the species of the genus Pagellus (Osteichthyes: Perciformes) in different areas of the Mediterranean. Sci. Mar. 66(Suppl. 2): 65-82. https://doi.org/10.3989/scimar.2002.66s2

Spedicato M.T., Lembo G., Carbonara P. 2003. Annotated check list of the skates (Chondrichthyes, Rajidae) in the Central-Southern Thyrrhenian Sea. Biol. Mar. Mediterr. 10: 941-945.

Spedicato M.T., Poulard J. C., Politou C. Y., et al. 2010. Using the ALADYM simulation model for exploring the effects of management scenarios on fish population metrics. Aquat. Living Resour. 23: 153-165. https://doi.org/10.1051/alr/2010015

Terribile K., Evans J., Knittweis L., et al. 2016. Maximising MEDITS: Using data collected from trawl surveys to characterise the benthic and demersal assemblages of the circalittoral and deeper waters around the Maltese Islands (Central Mediterranean). Regional Studies in Marine Science 3: 163-175. https://doi.org/10.1016/j.rsma.2015.07.006

Torre M., Kallianiotis A., Sicuro B., et al. 2011. Geographical and bathymetric distribution of silver scabbard fish Lepidopus caudatus in North Aegean Sea. Int. Aquat. Res. 3: 217-226.

Tserpes G., Fiorentino F., Levi D., et al. 2002. Distribution of Mullus barbatus and $M$. surmuletus (Osteichthyes: Perciformes) in the Mediterranean continental shelf; implications for management. Sci. Mar. 66(Suppl. 2): 39-54. https://doi.org/10.3989/scimar.2002.66s239

Tserpes G., Maravelias C. D., Pantazi M., et al. 2013. Distribution of relatively rare demersal elasmobranchs in the eastern Mediterranean. Estuar. Coast. Shelf Sci. 117: 48-53. https://doi.org/10.1016/j.ecss.2012.09.020

Tserpes G., Peristeraki P. 2002. Trends in the abundance of demersal species in the southern Aegean Sea. Sci. Mar. 66(Suppl. 2): 243-252. https://doi.org/10.3989/scimar.2002.66s2243

Tserpes G., Politou C.-Y., Peristeraki P., et al. 2008. Identification of hake distribution pattern and nursery grounds in the Hellenic seas by means of generalized additive models. Hydrobiologia 612: $125-133$.

https://doi.org/10.1007/978-1-4020-9141-4_10

Tserpes G., Tzanatos E., Peristeraki P. 2011. Spatial management of the Mediterranean bottom-trawl fisheries: the case of the south- 
ern Aegean Sea. Hydrobiologia 670: 267-274. https://doi.org/10.1007/s10750-011-0667-7

Tsikliras A.C., Peristeraki P., Tserpes G., et al. 2015. Mean temperature of the catch (MTC) in the Greek Seas based on landings and survey data. Front. Mar. Sci. 2: 1-6. https://doi.org/10.3389/fmars.2015.00023

Tugores M.P., Ordines F., Guijarro B., et al. 2019. Essential fish habitats and hotspots of nekto-benthic diversity and density in the western Mediterranean. Aquat. Conserv. 29: 461- 471. https://doi.org/10.1002/aqc.3031

Ungaro N. 2004. Biological parameters of the brown ray, Raja miraletus, in the Southern Adriatic basin. Cybium 28: 174-176.

Ungaro N., Marano G. 2002. On the distribution and demography of the deep-water pink shrimp and Norway lobster fishery stocks in the South Adriatic Sea. Stud. Mar. 23: 15-24.

Ungaro N., Gramolini R. 2006. Possible effect of bottom temperature on distribution of Parapenaeus longirostris (Lucas, 1846) in the Southern Adriatic (Mediterranean Sea). Turk. J. Fish. Aquat. Sc. 6: 109-115.

Ungaro N., Marano G., Auteri R., et al. 2002. Distribution, abundance and biological features of anglerfish (Lophius piscatorius and Lophius budegassa) in the Mediterranean Sea. Sci. Mar. 66(Suppl. 2): 55-66. https://doi.org/10.3989/scimar.2002.66s255

Ungaro N., Marano G., Pastorelli A.M., et al. 2004. Nuove informazioni sulla fauna ittica del basso Adriatico. Biol. Mar. Mediterr. 11: 648-651.

Ungaro N., Marano C. A., Ceriola L., et al. 2005. Distribution of demersal crustaceans in the southern Adriatic Sea. Acta Adriat. 46: $27-40$

Ungaro N, Marano G., Ceriola L., et al. 2005. Prime informazioni sulle taglie maturative di Raja clavata Linnaeus, 1758 e Raja asterias Delaroche, 1809 nel Basso Adriatico. Biol. Mar. Mediterr. 12: 598-601.

Vafidis D., Leontarakis P.K., Dailianis T., et al. 2008. Population characteristics of four deep-water pandalid shrimps (Decapoda: Caridea) in the northern Aegean Sea (NE Mediterranean). J. Nat. Hist. 42: 2079-2093. https://doi.org/10.1080/00222930802254672

Vallisneri M., Piccinetti C., Tommasini S. 2006. Age, growth, and gonad organization in red bandfish (Cepola macrophthalma L., 1758) from the Adriatic Sea. Acta Adriat. 47: 217-221

Vallisneri M., Scapolatempo M., Piccinetti C. 2007. Preliminary biological data on the northeast Mediterranean conger eel Conger conger L., 1758. Note. Bol. Inst. Esp. Oceanografía 23: 111-114.

Vallisneri M., Trotta V., Cavicchi S., et al. 2008. Sex-specific somatic-otolith growth relationship in two Gadidae. J. Fish Biol. 72: 724-730. https://doi.org/10.1111/j.1095-8649.2007.01708.x

Vallisneri M., S. Tommasini, M. Stagioni, C. et al. 2014. Distribution and some biological parameters of the red gurnard, Che lidonichthys cuculus (Actinopterygii, Scorpaeniformes, Triglidae) in the north - central Adriatic Sea. Acta Ichthyologica et Piscatoria 44: 173-180. https://doi.org/10.3750/AIP2014.44.3.01

Valls M., Quetglas A., Ordines F., et al. 2011. Feeding ecology of demersal elasmobranchs from the shelf and slope off the Balearic Sea (western Mediterranean). Sci. Mar. 75: 633-639. https://doi.org/10.3989/scimar.2011.75n4633

Valls M., Cabanellas-Reboredo M., Uranga I., et al. 2015. Feeding ecology of two squid species from the western Mediterranean. Mar. Ecol. Prog. Ser. 531: 207-219. https://doi.org/10.3354/meps 11347

Valls M., Rueda L., Quetglas A. 2017. Feeding strategies and resource partitioning among elasmobranchs and cephalopods in Mediterranean deep-sea ecosystems. Deep-Sea Res Part I. 128: 28-41. https://doi.org/10.1016/j.dsr.2017.09.002

Vannucci S., Mancusi C., Serena F., et al. 2006. Feeding ecology of Rays in the Southern Ligurian Sea. Biol. Mar. Mediterr. 13: 296-297.

Vasilakopoulos P., Maravelias C. D. 2016. Application of datalimited assessment methods on black anglerfish (Lophius budegassa Spinola, 1807) stocks in the Mediterranean Sea. J. Appl. Ichthyol. 32: 277-287. https://doi.org/10.1111/jai.12968

Vassallo P., D’Onghia G., Fabiano M., et al. 2017. A trophic model of the benthopelagic fauna distributed in the Santa Maria di Leuca cold-water coral province (Mediterranean Sea). Energ.
Ecol. Environ. 2: 114-124. https://doi.org/10.1007/s40974-016-0047-2

Vitale S., Andrews A., Rizzo P., et al. 2016. Twenty-five-year longevity of European hake (Merluccius merluccius) from novel use of bomb radiocarbon dating in the Mediterranean Sea. Mar. Freshw. Res. 67: 1077-1080. https://doi.org/10.1071/MF15376

Viva C., Reale B., Sbrana M. 2003. Annotated check list of the skates (Chondrichthyes; Rajidae) in the northern Tyrrhenian Sea. Biol. Mar. Mediterr. 10: 958-965

Viva C., Sartor P., Bertolini D., et al. 2015. Relationship of otolith length to fish total length in six demersal species from the NW Mediterranean Sea. J. Appl. Ichthyol. 31: 973-974. https://doi.org/10.1111/jai.12838

Voliani A., Cuccu D., Fiorentino F., et al. 2009. An updated review of the occurrence of Bathypolypus sponsalis (Cephalopoda: Octopodidae) in the Italian seas and notes on its distribution in the Mediterranean. Boll. Malacol. 45: 81-86.

Vrgoc N, Sifner Sk., Dadic V, et al. 2006. Demographic structure and distribution of John Dory, Zeus faber L. 1758, in the Adriatic Sea. J. Appl. Ichthyol. 22: 205-208. https://doi.org/10.1111/j.1439-0426.2006.00733.x

Zava B., D’Anna G., Giordano D., et al. 2005. Note biologiche su Lagocephalus lagocephalus (L., 1758) delle acque siciliane (Osteichthyes-Tetraodontidae). Biol. Mar. Mediterr. 12: 614-617.

Žuljević A., Akira F. P., Vedran N., et al. 2016. The Mediterranean deep-water kelp Laminaria rodriguezii is an endangered species in the Adriatic Sea. Mar. Biol. 163: 69-1. https://doi.org/10.1007/s00227-016-2821-2

Zupa R., Silecchia T., Carbonara P., et al. 2006. Crescita di Trachurus mediterraneus (Steindachner, 1868) nel Tirreno centromeridionale Biol. Mar. Mediterr. 13: 302-303.

Zupa W., Donnaloia M., Gaudio P., et al. 2010. Occurrence of Leucoraja fullonica (Linnaeus, 1758) in the South Adriatic Sea. Biol. Mar. Mediterr. 17: 260-261.

\section{PhD Thesis}

Altea P. 2016. Studio sulle diverse forme di adattamento della macrofauna all' ambiente profondo. Ph.D. thesis, Università di Cagliari, Italy.

Alvito A., 2014. Marine litter in Sardegna: Valutazione dello stato dei rifiuti bentonici come contributo alla Marine Strategy Framework Directory. Ph.D. thesis, Università di Cagliari, Italy.

Battista D., 2009. Indagine esplorativa sullo "stock vergine" e sull'habitat del gambero viola (Aristeus antennatus) nel Mar Ionio settentrionale. Ph.D. thesis, Università di Bari Aldo Moro, Italy.

Bellodi A. 2014. Applicazione delle chiavi età lunghezza allo stock assessment per l'identificazione di linee gestionali idonee alla tutela di alcuni raidi mediterranei. Ph.D. thesis, Università di Cagliari, Italy.

Bottari T. 2002. Studio delle lesioni da pesca a strascico in pesci, molluschi cefalopodi e crostacei decapodi. Ph.D. thesis, Università degli Studi di Messina.

Conti F. 2011. Valutazione dello stato di sfruttamento del gambero rosa Parapenaeus longirostris (Lucas, 1846) in aree del Mar Mediterraneo sottoposte a differente pressione da pesca: risultati di una serie storica di dati. Ph.D. thesis, Università degli Studi di Messina.

Ferrer Maza D. 2016. La salud de los peces comerciales: relación entre parasitismo, condición y potencial reproductor. Ph.D. thesis, Universidad de Valencia, Spain.

García-Merchán V.H. 2012. Estructura genética poblacional y discontinuidades oceanográficas en crustáceos decápodos. Ph.D. thesis, Universitat de Barcelona, Spain.

García-Ruiz C. 2012. Estudio de la distribución y diversidad ictiofaunística del mar de Alborán. Ph.D. thesis, Universidad de Málaga, Spain.

Guijarro B. 2012. Population dynamics and assessment of exploited deep water decapods off Balearic Islands: from single to multispecies approach. Ph.D. thesis, Universitat de les Illes Balears, Spain.

Joher Sais S. 2016. Macroalgal-dominated coastal detritic bottoms of the Mediterranean Sea and the Northeastern Atlantic: description, distribution and sampling methodologies. Ph.D. thesis, Universitat de Girona, Spain.

Keller S. 2017. Life-history, ecology and fisheries of cephalopods in the western Mediterranean. Ph.D. thesis, Universitat de les 
Illes Balears, Spain

Koutsidi M. Functional characteristics and ecology of Mediterranean fishery catches: connecting fish characteristics with environment and ecosystem functioning. Ph.D. thesis, University of Patras, Greece.

Modica L. 2011. Approccio ecosistemico allo studio della popolazione di Merluccius merluccius. Ph.D. thesis, Università degli Studi di Genova.

Marongiu M.F. 2014. La riproduzione nei condroitti come elemento chiave per la loro conservazione e gestione nel Mediterraneo centro-occidentale. Ph.D. thesis, Università di Cagliari, Italy

Marra M., 2013. Genetica di Popolazione e Filogeografia di Aristeus antennatus (Crustacea: Decapoda) nel Mar Mediterraneo. Ph.D. thesis, Università di Bari Aldo Moro, Italy.

Moranta J. 2007. Deep western Mediterranean demersal fish communities. Ph.D. thesis, Universitat de les Illes Balears, Spain.

Mulas A. 2009. Interazioni trofiche tra Condroitti in Mediterraneo. $\mathrm{Ph} . \mathrm{D}$. thesis, Università di Cagliari, Italy

Ordines F. 2016. Benthic habitats, demersal communities and population dynamics of fishes on the circalittoral soft bottoms of the Balearic shelf (western Mediterranean). Ph.D. thesis, Universitat de les Illes Balears, Spain.

Paradinas Aranjuelo I. 2016. Characterization of important deep water ecosystems for fisheries sustainability: European hake as a case study. Ph.D. thesis, Universidad de Valencia, Spain.

Pennino M.G. 2013. Implementing Ecosystem Approach to Fisheries Management: Advances and New tools. Ph.D. thesis, Universidad de Valencia, Spain.

Perdichizzi A. 2009. Dinamica di popolazione e pesca sostenibile dei gamberi profondi: il caso del mar Tirreno meridionale. $\mathrm{Ph} . D$. thesis, Università degli Studi di Messina.
Pesci P. 2013. Ecologia, Biologia e Struttura di popolazione delle triglie Mullus barbatus Linneo, 1758 e Mullus surmuletus Linneo, 1758 nei mari circostanti la Sardegna. Ph.D. thesis, Università di Cagliari, Italy

Puerta P. 2015. Spatial ecology of harvested cephalopods in the Western Mediterranean. Ph.D. thesis, Universidad Internacional Menéndez Pelayo, Spain.

Quetglas A. 2003. Bottom trawling cephalopod fauna from the Balearic Sea (Western Mediterranean). Ph.D. thesis, Universitat de les Illes Balears, Spain

Ramírez-Amaro S. 2017. Past and recent demographic histories of western Mediterranean demersal chondrichthyans. Ph.D. thesis, Universitat de les Illes Balears, Spain.

Ricci P., 2017. Il ruolo delle specie keystone nella comunità demersale del Mar Ionio Settentrionale: aspetti strutturali, funzionali e gestionali. Ph.D. thesis, Università di Bari Aldo Moro, Italy.

Rufino, M.M.. 2004. Distribution of Liocarcinus depurator along the western Mediterranean coast. Ph.D. thesis, University of Wales-Bangor, United Kingdom.

Simão, D.S. 2013. Distribución y biología de poblaciones de crustáceos decápodos pelágicos en el Mediterráneo occidental. Ph.D. thesis, Universitat Politècnica de Catalunya, Spain.

Valls M. 2017. Trophic ecology in marine ecosystems from the Balearic Sea (western Mediterranean). Ph.D. thesis, Universitat de les Illes Balears, Spain.

Vittori S. 2013. Un approccio multidisciplinare per l'identificazione dello stock del nasello (Merluccius merluccius, Linnaeus 1758) nei mari sardi. Ph.D. thesis, Università di Cagliari, Italy. 